\title{
Review of recent research (1998-2012) in German for Academic Purposes (GAP) in comparison with English for Academic Purposes (EAP): cross-influences, synergies and implications for further research
}

Article

Accepted Version

Jaworska, S. (2015) Review of recent research (1998-2012) in German for Academic Purposes (GAP) in comparison with English for Academic Purposes (EAP): cross-influences, synergies and implications for further research. Language Teaching, 48 (2). pp. 163-197. ISSN 1475-3049 doi: https://doi.org/10.1017/S026144481400038X Available at https://centaur.reading.ac.uk/37172/

It is advisable to refer to the publisher's version if you intend to cite from the work. See Guidance on citing.

To link to this article DOI: http://dx.doi.org/10.1017/S026144481400038X

Publisher: Cambridge University Press 
copyright holders. Terms and conditions for use of this material are defined in the End User Agreement.

\section{www.reading.ac.uk/centaur}

\section{CentAUR}

Central Archive at the University of Reading

Reading's research outputs online 


\title{
Review of recent research (1998-2012) in German for Academic Purposes (GAP) in comparison with English for Academic Purposes (EAP): cross-influences, synergies and implications for further research
}

\author{
Sylvia Jaworska \\ English Language and Applied Linguistics \\ Reading University \\ Reading RG6 6AW \\ UK
}

\section{Abstract (English)}

This state-of-the-art review reports on the major studies conducted in the field of Deutsch als Wissenschaftssprache (academic German) since the late 1990s. To begin with, the current position of German as a language of academic communication nationally and internationally will be discussed, focusing especially on the challenges posed by the status of English as a lingua franca. Subsequently, the major research undertaken since the late 1990s will be reviewed and its contribution to the development of teaching materials evaluated. Since studies on academic German have been influenced, to some extent, by research in English for Academic Purposes (EAP), this paper also attempts to dovetail developments in EAP in order to highlight commonalties and differences. The final sections will discuss some potential synergies and implications for further research in both fields.

\footnotetext{
Abstract (German)
} 
Ziel des Beitrags ist es, einen Überblick über den Forschungsstand im Bereich Deutsch als Wissenschaftssprache (DaW) zu geben. Dabei wird hauptsächlich auf empirische Arbeiten und Forschungsprojekte eingegangen, die in den letzten 15 Jahren abgeschlossen wurden. Zuerst wird der gegenwärtige Status des Deutschen als Wissenschaftssprache in dem wissenschaftlichen Betrieb in den deutschsprachigen Ländern und international kurz besprochen. Ein besonderes Augenmerk wird dabei auf die Problematik gelegt, die durch die Dominanz des Englischen entstanden ist. Darauf folgend werden empirische Studien, die sich mit vielfältigen Aspekten der wissenschaftlichen Kommunikation auf Deutsch befassten, dargestellt und kommentiert. Da viele der Arbeiten didaktischen Zielsetzungen folgten, werden auch anschließend einige neue Ansätze zur Vermittlung des Deutschen als Wissenschaftssprache diskutiert. DaW hat sich in den letzten 20 Jahren zu einem eigenständigen und dynamischen Forschungsfeld entwickelt, das hinsichtlich der Vielfalt und Tiefe der Themen seinem englischen Pendant English for Academic Purposes (EAP) in nichts nachsteht. Nichtsdestotrotz kann EAP, das ein umfangreicheres Forschungsgebiet darstellt, viele neue Impulse liefern. Abschließend werden einige theoretische und methodische Aspekte aufgegriffen, die die Forschung in EAP und DaW anregen und bereichern könnten.

Sylvia Jaworska is a Lecturer in Applied Linguistics at Reading University. She completed her PhD in 2007 at Aston University (Birmingham, UK) in the area of language policy and language teaching with special reference to German as a Foreign Language. She is particularly interested in the use of corpus tools and methods to investigate the lexical development in English and German L2 as well as lexical features of academic discourse in both languages. She also combines discourse analysis with corpus linguistics to examine discursive strategies in gendered and racist language. 


\section{Introduction}

The main purpose of this paper is to offer an overview of research conducted in the field of Deutsch als Wissenschaftssprache 'academic German'. This overview primarily discusses results of empirical studies focusing on the research interests pursued since the late 1990s. It also highlights some concerns and controversies that have recently stimulated debates in this field. Since studies on academic German have been influenced, to some extent, by research in English for Academic Purposes (EAP), this paper attempts to dovetail developments in EAP in order to highlight commonalties and differences between both fields. It also seeks to identify potential synergies and implications for further research.

The first part of this article attempts to clarify the disciplinary scope and objectives of research concerned with academic German. It focuses on the question of terminology, specifically on how the term Deutsch als Wissenschaftssprache 'academic German' differs from the early definitions of Fachsprache 'specialist language'. Given that research on academic German foregrounds the functional dimension and is concerned with pedagogical matters, the term Deutsch als Wissenschaftssprache seems rather narrow. In line with EAP, I propose to use the term German for Academic Purposes (GAP), as it better accounts for the many facets of research concerned with academic German and emphasises the functional and pedagogical aims. Since some readers may not be familiar with, or have only little knowledge of, research undertaken within GAP, the second part of this article offers a brief historical overview of the main linguistic influences and research directions that have been pursued since 1960s. Following on from this, section 3 discusses the current international and national status of academic German. It focuses especially on the challenges that the dominance of English as lingua franca poses for German as a language of academic communication nationally and internationally. Section 4, which is the core of this article, reports on the major studies on academic German carried out since the late 1990s, while 
section 5 briefly evaluates the contribution of this research to the development of teaching materials. The final section summarises the main research areas and directions in GAP and compares them with the developments in EAP. Subsequently, issues which have received little attention in research are discussed and potential GAP and EAP research synergies are outlined.

\section{Scientific German, Academic German or German for Academic Purposes?}

In the German-speaking contexts, the term Deutsch als Wissenschaftssprache (DaW) 'academic German' has been used first and foremost to denote the language of science in its broader sense, although differentiations were made between the use of $\mathrm{DaW}$ in different (scientific) domains. Hence, terms such as language of mathematics or language of medicine have also been adopted to highlight the specific professional context of usage. At this point, it is important to note that the German noun Wissenschaft should not be solely equated with SCIENCE in the English sense of the word, as it is often done in popular translations. Since Leibniz, the term Wissenschaft and its adjectival derivative wissenschaftlich have had, in the German-speaking context, a much broader meaning including natural sciences (Naturwissenschaften) and humanities

(Geisteswissenschaften). A direct equivalent does not exist in English and the closest translation seems to be the adjective ACADEMIC. The term SCIENTIFIC when used here will specifically refer to research undertaken in (natural) sciences.

In early years, research in academic German was pursued within Fachsprachenforschungthe German branch of research dedicated to Languages for Special Purposes (LSP). Since its establishment in the 1960s, LSP has been preoccupied with terminology. This had influenced research on academic German in that in early DaW research focused on specialist vocabulary. This rather narrow understanding of DaW has been criticised at least since the early 1990s. With the development of new linguistic disciplines, especially Pragmatics and Text Linguistics, a 
number of prominent German linguists such as Weinrich (1993), Ehlich (1993, 1995) and Kretzenbacher (1998a) argued for the expansion of the scope and objectives of DaW and for the establishment of the field as a research subject in its own right. In contrast to other specialist languages, it was stressed that Wissenschaftssprache 'academic language' forms a very different field of linguistic inquiry. Following from Weinrich (1993), Kretzenbacher (1998a) points to three distinctive features that distinguish academic language from, for example, the language of business or sport. Firstly, academic language plays a constitutive role in the process of knowledge formation and dissemination. As Kretzenbacher (1998a) highlights, academic facts do not exist outside language, but are co-constructed and discursively negotiated through the medium of language. Even in fields such as physics, language with its repertoire of metaphors is an indispensable tool for knowledge construction. Secondly, academic language is a form of institutionalised communication which is inherently dialogical in nature and this applies not only to spoken academic genres. The dialogical character of academic texts is manifested through the use of citations and bibliographies that place each new text in a particular academic discourse or tradition. Kretzenbacher (1998a) refers to this dialogical character as the intertextual dialogue of academic communication. Finally, academic language is essentially a product of a particular culture, where CULTURE can be understood in three distinctive ways. Firstly, academic language is a product of a national language culture with its underlying conventions of what is the appropriate way of speaking and writing about academic subject matters (interlingual dimension). Secondly, each academic discipline develops its own distinctive way of talking and speaking about its subject including specialist vocabulary (extra-disciplinary dimension). Thirdly, it is normally expected that each academic domain should engage in dialogue with other disciplines (interdisciplinary dimension) as well as with the public. The latter form of engagement leads to a contact situation with ordinary everyday language and this, in turn, fosters the development of 
new linguistic forms and practices. Given the essential role of language as a constitutive and constituting element in the knowledge construction and dissemination, it is evident that the focus on just specialist vocabulary is too narrow to account for the many facets that shape academic communication. For this reason, Kretzenbacher (1998a: 134) proposes a new broader definition of academic language as the entirety of all linguistic phenomena that occur in academic communication that are, at the same time, constitutive elements of knowledge production and dissemination. This includes the cultural and institutional practices that determine the process of knowledge creation. While this definition offers a much more adequate account of German as an academic language, there are still two important facets that Kretzenbacher left out in his elaborations. Firstly, it is not a coincidence that the development of $\mathrm{DaW}$ as an independent field of linguistic inquiry was closely related to the developments in the field of Deutsch als Fremdsprache (DaF) 'German as a Foreign Language' (GFL). Many of the linguists who pleaded for DaW to become a research field in its own right were, at the same time, involved in research and teaching of DaF. Hence, it is not surprising to see that beyond the descriptions of linguistic features of academic German, the field of DaW was, from the outset, committed to pedagogical aims and needs (cf. Fandrych \& Graefen 2010). Secondly, most conceptual thinking about DaW operates with the term Wissenschaftssprache 'academic language', which seems to imply the existence of one all-encompassing academic variety. In light of the recent sociolinguistic and anthropological critique of the narrow understanding of the label LANGUAGE (Blommaert 2005: 10), one can arguably ask whether Wissenschaftssprache 'academic language' is an adequate term to account for the variety of domain-specific, professional, social and geographical parameters as well as styles and formats of academic communication. This terminological issue has not yet received much attention in the German-speaking countries. However, some scholars tend to use the noun in plural as Wissenschaftssprachen 'academic languages' (Fluck 2010; 
Heine 2010; Kretzenbacher 2010), whereas others increasingly favour the term Wissenschaftsdiskurs 'academic discourse'. For example, Günthner \& Knoblauch (2007) use the term to refer to the entirety of communication forms, genres, registers, media and other resources (such as technology) that are used to establish academic communities, their disciplines and traditions.

EAP looks back at similar developments. This field too was conceived within the broader field of English for Specific Purposes (ESP) and became an independent research discipline 20 years ago with the rapidly growing number of non-native speakers attending English-speaking universities (Hyland \& Hamp-Lyons 2002). Pedagogical considerations are high on the EAP agenda. In fact, EAP is understood as an area of language research that is to foster the development of academic literacy. This is perhaps one of the reasons why the term English for Academic Purposes was chosen, as it puts stronger emphasis on the applied, functional focus, something which, for example, the term academic English does not do. As will be seen in the following sections, teaching-related concerns provided a direct impetus for research in the field of DaW and many of the research projects reported below set to improve the level of academic writing. Hence, referring to the field as academic German would be rather narrow. Similar to EAP, the term German for Academic Purposes (GAP) seems more adequate, as it better accounts for the diversity of theoretical and practical concerns investigated by researchers working in this field.

\section{A brief historical overview of research traditions in GAP}

Since the 1970s, there has been growing interest in the linguistic analysis of academic German, though the field of GAP did not exist at that time and this interest evolved within the field of Fachsprachenforschung 'languages for special purposes' (Schröder 1991a). Academic German 
was understood as a specialist language used in academic contexts and no conceptual distinctions were made between academic German and other linguistic varieties used for professional purposes. Around this time, a belief held sway that specialist languages did not substantially differ from everyday language except for the heavy use of terminology (Schröder 1991a). Most research conducted under the banner of LSP was at this stage mainly interested in identifying the frequent and typical academic lexis and was influenced by the traditional Wortartengrammatik 'parts of speech grammar'. The three volumes by Erk $(1972,1975,1982)$ - each dedicated to a different part of speech and their frequencies- are the paramount example of this type of research. Although he did not have sophisticated linguistic software at his disposal, his work offers an incredibly detailed and comprehensive account of academic lexis, which goes beyond the use of terminology.

Parts of speech have been the basis of many studies in GAP ever since. However, in the following decades a new perspective on lexis began to hold sway. From the 1970s onwards, Pragmatics, or more specifically Functional Pragmatics grew to become a mainstream theory in Linguistics in the German-speaking countries. Similar to Sociolinguistics, Functional Pragmatics (FP) is based on the view of language as a social construct. However, FP is not so much concerned with linking language use with selected social variables. Its underlying premise is the understanding of language, as a societal action and a means to fulfil a variety of extralinguistic and linguistic purposes (Redder 2008). This new understanding of languages and especially the category of PURPOSE led to a functional-communicative turn in studies concerned with LSP (Schröder 1991b). Inspired by the work of the Prague School, research attention was shifted towards the examination of functions in academic texts, though the main unit of analysis was, at this stage, the sentence. Indicative of this development is the work of Beneš $(1966,1981)$ on the functional sentence perspective and syntactic structures of academic texts. The shift towards 
communication and functional aspects of language use initiated a subsequent move from the analysis of isolated syntactic features towards larger textual units. In fact, at the beginning of the 1980s, 'text' became the starting point for linguistic analysis. The textual approach was a product of the then fast developing branch of Textlinguistik 'Text Linguistics', which presented an interesting synergy of stylistics, literary theory and functional linguistics as best represented by the work of de Beaugrande \& Dressler (1981) and Brinker (1983). Although GAP was not an independent research field yet, the shift to the textual approach had a considerable impact on research in this field. Soon researchers began to examine selected academic text types, their structure, and organisation, as well functional features (e.g. Dressler 1983; Fluck 1988). Parallel to the development of discourse analysis in English-speaking countries (e.g. Coulthard 1977), increasingly attention was paid to discursive and stylistic features of academic texts, as demonstrated in work by Markkanen \& Schröder (1997), Clyne (1991) on hedges and Clyne \& Kreutz (1987) on digression and other discourse structures. There were also first attempts to identify register features of spoken and written academic language (Spillner 1982).

At the beginning of the 1980s, a new research orientation emerged in the field of text linguistics, which soon stimulated a number of studies on academic German. Influenced by Kaplan's (1972) pioneering work on contrastive rhetoric and research on cross-cultural communication (e.g. House \& Kasper 1981), researchers turned their attention towards the examination of similarities and differences in academic texts produced in different cultural contexts. Academic language was not seen as a universal kind of a specialist language anymore, but as a product of a particular academic culture. The starting point for this new strand of research was the sociological work by Galtung (1985) on different intellectual styles. Although his concept of four distinctive styles is not based on solid empirical evidence and is rather impressionistic, it nevertheless stimulated comparative research on cultural differences in the 
organisation of German academic texts as well as academic texts produced in German by nonnative speakers (Clyne 1987; Eßer 1997; Hufeisen 2002). The interest in the non-native speaker was also triggered by linguistic challenges faced by non-native students whose number has been continuously growing since mid 1990s (Statistisches Bundesamt 2012). Soon it was recognised that the communicative needs of non-natives studying at German universities are different from that of ordinary learners of German as a Foreign Language (Ehlich 1995, 1999). This shifted the attention from genuine academic texts such as academic paper or abstract to texts required from students, for example, Seminararbeit 'student essay' or Referat 'seminar presentation'. Comparisons of textual and lexico-grammatical properties of texts produced by native and nonnative students were thought to offer important insights into the cross-cultural differences in academic writing and provide suggestions for the development of better pedagogical resources. It is perhaps not a coincidence that this strand of research developed at universities in Munich, Hamburg and Vienna - also vibrant centres of research in German as a Foreign Language.

Methodologically, most research on academic German is based on analytical tools and methods developed within Text Linguistics and Functional Pragmatics. Many of the studies have a comparative and contrastive focus. It is precisely this functional and cross-cultural tradition that has strongly influenced research in GAP since the 1990s and contributed to the establishment of GAP as a research field in its own right. An overview of this newer research (since the late 1990s) will constitute the main part of this article. Research conducted in the early phases has been extensively reviewed elsewhere (Schröder 1991b; Hoffmann, Kalverkämper \& Wiegand 1998; Niederhauser 1999) and will not be detailed here.

\section{GAP: the current status and debates}


Academic German has been losing its importance as an international language of academic communication since the end of the First World War. While in the $19^{\text {th }}$ and at the beginning of the $20^{\text {th }}$ century, German was, alongside English and French, the dominant language in many academic disciplines, especially in chemistry, medicine and biology, 100 years later it leads a rather shadowy existence in the global academic community (Ammon 1998, 2001; Reinbothe 2006). The most comprehensive studies on the international status of academic German have been conducted by Ammon $(1998,2001)$. By looking at two indicators a) citations of German publications in the major citation indices and b) the number of German Nobel prize winners, Ammon (2001) provided some quantitative evidence documenting the steady decline of German in academic/scientific fields.

There are numerous reasons for this state of affairs. The most frequently cited ones are: the boycott of German and Austrian scientists following the First World War (Reinbothe 2006), the atrocities during the Nazi era and the subsequent exodus of scientists from Germany mainly to the United States (Ammon 1998). There is no doubt that the two World Wars are largely responsible for the decline of German as an international language of academic communication. However, as Ammon (2004) observes, they only accelerated what was bound to happen.

At the beginning of the $20^{\text {th }}$ century, the United Stated became the world's power centre in terms of the political, economic, scientific and technological development. The Americans had also a powerful tool at their disposal - the English language, which, given its global status due to the British colonisation, was destined to become the new lingua franca of academic communication (Ammon 2004). Apparently, Bismarck was already aware of this linguistic power that the North Americans possessed. When asked what the most important factor would be in modern history, he said, the fact that the North Americans speak English (Crystal 2004: 30). Besides, it should not be forgotten that alongside the US, other English speaking countries such 
as Canada and Britain were able to make much larger investments into Higher Education and the scientific development post 1945 than Germany.

There was also another important contributor to the demise of German and other languages in academic communication, namely the abolishment of a foreign language requirement at American universities in the 1960s (Ammon 2004). This led to a dramatic decline of the reception of academic work published in languages other than English. To put it simply, American scientists and academics had neither the need nor the skills to read and interpret research conducted in non-English speaking countries. Conversely, non-English speaking scientists who wanted to be heard and recognised beyond the borders of their own countries had to start publishing in English. This is now the status quo, particularly in natural sciences. A survey conducted by Skudlik (1990) at the beginning of the 1990s revealed that approximately $88 \%$ of German biologists and 74\% of German physicians published in English. Ammon (2001) concludes that the more theoretical a discipline is, the more likely is the use of English. Arts and humanities tend to remain the bastions of national languages because of their links to cultural heritage (Duszak 1997). However, in Germany this is currently being challenged due to the increasing efforts to internationalise German universities on par with academic institutions in English-speaking countries.

One of the major initiatives under the banner of 'internationalisation' has been the introduction of international degree programmes in order to attract more foreign students. The popularity of the international degrees has been growing quickly since they were first established at the end of the 1990s. Currently, there are more than 1000 such programmes on offer including BA, Master and PhD level courses, mostly in engineering, business, management and other branches of natural and social sciences. There are also a growing number of international programmes offered in the humanities. Most of these programmes use English as the medium of 
teaching. In addition, in 2001 a new private university was established in the northern German city of Bremen - the Jacobs University, which offers degree programmes exclusively in English, including in the social sciences and humanities.

Despite the enthusiasm for internationalisation and its success - Germany is now the third largest global recruiter (Coleman 2006) - the burgeoning use of English as the language of academic publications and conferences, and the growing number of English-medium degree programmes has recently given rise to concerns about the position of German-speaking scholars in the global academic community as well as the future of German in research and university teaching in German-speaking countries. For example, in 2010, the prominent organisation Deutscher Akademischer Austauschdienst (DAAD) 'German Academic Exchange Service' issued a memorandum in support of academic German against the dominance of English. This was also a topic of a number of conferences and workshops organised recently in Germany, for example by the DAAD and the Goethe-Institut. The issue seems to be of concern not only to scientists, scholars and academic institutions. It has also been hotly debated amongst the wider public as evidenced by coverage it received in national newspapers. The following headlines are a few examples of the fear evoked by English as the dominant language: 'Soll Deutsch als Wissenschaftssprache überleben?' 'Should German as an academic language survive?, 'Sprachfreies Denken gibt es nicht' 'There is no thinking independent of language' or 'Kulturstaatsminister Julian Nida-Rümelin erklärt Deutsch als Wissenschaftssprache für "tot”،“، 'The minister of culture Julian Nida-Rümelin declares academic German “dead”“.

Many of the academic voices within the critical camp are not necessarily concerned with English as such but with the academic monolingualism which the overwhelming presence of English in academic discourse would predictably lead to. By drawing on the Humboldtian concept of the interdependence of language and thought and the Sapir-Whorf hypothesis of 
linguistic relativism, they point to the symbiotic relationship between (national) language and academic concepts (e.g. Schiewe 2007). They argue that intellectual/scientific thinking is firmly grounded in the given (national) language and culture and it is precisely the plurality of languages and cultures that has sparked creativity and advanced knowledge (Ehlich 2000; Ammon 2004; Földes 2005). With regard to this, Ehlich (2000) points to the GNOSEOLOGICAL function of language, i.e. the fundamental role of language in the process of knowledge creation. A good example of this symbiotic relation is terminology, which is often determined by the given language structure and deeply rooted in the culture in which it was formulated. One only has to think about the nomenclature created, for example, by Kantian metaphysics, Hegelian philosophy or Freudian psychoanalysis. Constructions such as Ding an sich 'a thing as it is in itself' or Überich 'super ego' are only possible as such in German due to its particular linguistic structure (Ehlich 2000). Another example is metaphors that are essentially cultural products and permeate the scientific/ academic discourse (Graefen 2009). Furthermore, as demonstrated in cross-cultural comparative research, different national language groups apply different text-organisational and rhetorical principles when conceptualising and discussing scientific/academic matters. This is a result of historical processes that contributed to the development of different ways and methods of doing research. It is through the exchange of different approaches that new insights are gained and ultimately knowledge enhanced. If the global academic community were to rely on only one language, then ultimately this diversity of research approaches would diminish and hence there would be less opportunity for intellectual innovation. Related to this is the issue of knowledge dissemination. If one language were to dominate scientific/academic inquiry, then only those who are proficient in that language would be able to benefit from it. As Ehlich (2006: 26) pointedly remarks, academic knowledge would become (again) GEHEIMWISSEN 'secret knowledge' available to a privileged group, as it was the case in medieval times. This would be against the 
scientific/ academic ethos which stresses free access to knowledge, also guaranteed by article 27 of the Universal Declaration of Human Rights. It would also violate the general democratic principles governing most of modern societies. Furthermore, it is argued that academic monolingualism would stifle linguistic creativity and ultimately lead to the Verarmung 'impoverishment' of not only terminology but also the national language as a whole and, in consequence, society (Ehlich 2006).

Many of these arguments are not new for those working or interested in EAP, as they have been extensively discussed in literature. Prompted by the notion of linguistic imperialism coined by Phillipson (1992), many EAP scholars pointed to inequalities which the dominance of English has created, for example, in access to knowledge and research funding (Benesch 2001; Canagarajah 2002a; Salager-Meyer 2008). As demonstrated by Salager-Meyer (2008), there is a strong link between the number of publications and citations in English, and the scientific and economic development of a country or region. It seems indeed that the world is divided into two halves: the developed industrialised scientific hub or centre, which is English-speaking and the developing world or the periphery, predominantly non-English. Scholars from the periphery are doubly hit; they have no or very limited access to resources, including prestigious publications in English and little possibilities to acquire academic English. Hence, they are less likely to publish in English and if they know some English, they tend to use it for reading purposes. This creates a division between the English-speaking centre, which produces and disseminates knowledge and the periphery, which becomes a mere recipient or consumer of that knowledge (Duszak 1997).

The arguments discussed by the EAP theoreticians and practitioners have been reported at length elsewhere and will not be reviewed here. However, for the purpose of this article, it is perhaps worth pointing out that Germany is, after all, one of the world leaders in the scientific and technological development and hence, cannot be really positioned in the periphery. 
According to the International Science Ranking ${ }^{1}$, it occupies the $5^{\text {th }}$ place in the world just after US, China, UK and Japan. Besides, there have been huge investments in science and educationand German scholars can benefit from a range of well-funded networking opportunities with academics/ scientists from abroad. Above all, English is the first foreign language taught in the German-speaking countries and there are plenty of opportunities to enhance one's own English skills - something which is not easily available in the periphery. Finally, it is also important to remember that the German academic tradition has been deeply monolingual itself and it was only the recent spread of English that, to some extent, imposed a more multilingual outlook. All in all, those who tend to pronounce Deutsch als Wissenschaftssprache 'academic German' dead and prophesy a demise of the scientific development in the German-speaking countries should be reminded about the privileged position which German-speaking academia and researchers still enjoy.

Nevertheless, the dominant status of English in academic discourse poses a number of challenges. Undoubtedly, there is a need for strengthening the linguistic diversity within the academic community. Within EAP, a number of initiatives have been proposed to account for the needs of non-native speakers. For example, language courses such as English for Academic Purposes have been developed, and new editing practices such as double publishing (i.e. the republishing of foreign language research articles in English) have been introduced (Hamp-Lyons 2011). As Salager-Meyer (2008) observes, such initiatives are certainly commendable. However, ultimately they strengthen the status of English. To achieve true linguistic diversity, more concerted efforts are needed on the part of national governments, research funding bodies, and private and commercial publishers. On the GAP front, Ehlich (2006) argues that Europe with its linguistic diversity could lead by example. He has pleaded for an establishment of a European Institute for Comparative Studies in Sciences and Humanities (Institut für 
Wissenschaftskomparatistik) under the auspices of the European Union. Given that academic communication is increasingly international, even if conducted only in English as L1 or L2, the existence of such an institute could stimulate research on cross-cultural features of academic discourse and contribute to a better understanding of the intercultural dimension of academic exchanges. Other practical steps suggested by Ehlich (2006) include the use of different languages at international conferences supported by teams of translators, the development of exchange programmes, and multilingual citation indices.

Another important initiative which could potentially counteract the growing academic monolingualism, but is rarely mentioned in research literature, is the introduction of a modern foreign language (MFL) requirement at tertiary level in English-speaking countries. Currently, the MFL-sector is in a sharp decline in most Anglophone countries and Higher Education (HE) seems to be particularly affected (Coleman 2004). The UK can serve here as a paradigmatic example (Jaworska 2009). Interestingly however, a recent report of the British Academy entitled 'Language Matters' stresses that despite the use of English as a lingua franca, UK-born academics and scientists are losing many opportunities to work or to collaborate on international projects, because they speak only English. ${ }^{2}$ They may also find it difficult to compete with colleagues who speak (an)other language(s). It seems that strengthening the ML sector in Anglophone HE would not only foster the development of academic multilingualism, but also assist the monolingual English-speaking scholars in developing new international research partnerships and collaborations.

It remains to be seen whether the suggestions made in research literature will meet with a broader socio-political response. So far, very little has happened. As Salager-Meyer (2008) points out, any long-term solutions cannot be successful without the involvement of political and 
research funding bodies. In the present economic climate and in light of cuts to Higher Education, it is very unlikely that the situation will change in the near future.

Apart from the socio-political challenges, the increasing dominance of English in academia, particularly in Europe, raises a number of questions that require answers drawn from empirically substantiated data. One of the major issues is the question of the advantages and limitations of teaching through the medium of English in Higher Education in a variety of non-English speaking settings. So far, there has been little research into the discursive practices and challenges which the use of English at tertiary level outside the Anglophone countries poses. In EAP, most of the studies focused on the situation in Hong Kong (e.g. Tung, Lam \& Tsang 1997). Recently, this issue has attracted some attention in the German-speaking context and there is now some literature available offering empirical insights and conceptual discussions on the use of English as a medium of instruction in Higher Education (Gnutzmann 2008; Smit 2010; Fandrych \& Sedlaczek 2012). For example, by adopting an ethnographic approach, Smit (2010) examined classroom discourse in one multilingual, but English-taught setting - a hotel management course. Her analysis revealed that overall English was a successful means of discussions and meaning negotiation. However, there were also a number of problems that hindered communication particularly at the beginning of the course, such as difficulties understanding English spoken with different accents, different proficiency levels in English, and switches to German - a language of which most students had little or no knowledge.

Another important issue is the question of how linguistic diversity contributes to the development of knowledge, especially through creativity and innovation (Ehlich 2006). Although many assume a link between multilingualism and the advancement of knowledge, there is surprisingly little empirical evidence to substantiate this claim. 


\section{Recent research on academic German}

With the establishment of Functional Pragmatics and Text Linguistics as independent fields of linguistic inquiry, the vast majority of studies on academic German since the early 1980s have been concerned with the textual and discursive characteristics of academic texts. While in the early phase there was a greater interest in terminology and syntactical and morphological aspects, these areas are now, with a few exceptions, less prominent.

This section will report on the major studies carried out since the late 1990s. Similar to EAP, the bulk of GAP research has been, to date, concerned with written academic discourse. It was only recently that spoken academic language began to occupy researchers' attention. Given the distinctiveness and complexity of spoken academic discourse (e.g. Biber, Conrad \& Cortes 2004), it was felt that this area should be discussed separately. Therefore, this section is divided into two parts. The first part is dedicated to written academic German. It consists of two subsections, which review studies of lexis, and pragmatic and textual aspects, including research undertaken from the cross-cultural and comparative perspective. The second part focuses exclusively on studies concerned with spoken academic German.

\subsection{Lexis}

Early studies of academic German were preoccupied with investigations into the specific academic vocabulary, particularly the use of Fachterminologie 'specialist terminology'. It was commonly believed that specialist vocabulary constituted the main feature of academic language as opposed to ordinary, everyday speech. Researchers extensively investigated the frequency, scope and origin of specialist terms as well as the problem of polysemy and synonymy (cf. Fluck 2001). This research strand was very productive, leading to publications of specialist dictionaries, word lists and manuals. However, in the mid 1990s, a new dimension was added to this research 
strand. Drawing on the observation that non-native speakers of German have particular difficulties with lexical items that are placed 'zwischen den Fachtermini' 'between the specialist terms' (Ehlich 1999: 8), Ehlich called for a stronger consideration and empirical research into non-specialist academic vocabulary which he termed ALLTÄGLICHE WISSENSCHAFTSSPRACHE ‘ordinary academic language' (Ehlich 1993, 1995). The concept refers to those elements of academic vocabulary that are essentially taken from everyday language/speech for the purpose of talking and writing about academic subject matters. Many of these elements have a metaphorical and/ or formulaic character.

This plea has instigated some research interest in the GAP community. The first empirical study on the subject was by Graefen (1999). On the basis of a text corpus comprising 23 articles from different disciplines, she attempted a classification of such ordinary academic lexis, which she divided into two groups: logical-methodological and cognitive-communicative types. While the former includes words and word combinations used for conceptualisations of theories and methods (e.g. unter einem Begriff zusammenfassen 'to summarise with a term'), the latter comprises of lexis referring explicitly to procedures used by the author/researcher (e.g. Ergebnisse vorstellen 'to demonstrate results'). Although most of the ordinary academic lexis is centred on nouns, Graefen (1999) points to the importance of ordinary verbs that require new shades of meanings when used in academic discourse. She demonstrates this by analysing the semantic valency of some of the verbs frequently used in academic papers. Detailed examinations of the semantic and functional aspects of ordinary academic lexis are relevant for the development of pedagogical resources. As Graefen (1999: 235) remarks, so far both native and non-native students normally have lists with noun-verb combinations at their disposal. Although such lists are useful, they do not reveal the semantic diversity as well as the many functional uses that ordinary nouns and verbs acquire in academic contexts. 
Ordinary academic verbs, especially their metaphorical and formulaic character, were the focus in a number of studies by Fandrych $(2001,2002,2006)$, two of which examined German and English comparatively. The starting point for Fandrych's analyses is the concept of a functional WISSENSRAUM 'knowledge space' proposed earlier by Redder (1990). The spatial dimension is a particularly conspicuous feature of academic German, which contains a wide repertoire of deictic elements, many of which are attached to verbs, the so-called particle and double particle verbs such as herausstellen 'to raise an issue' or hervortreten 'to emerge' (Fandrych 2006). Many of such verbs have a distinctive metaphorical and formulaic character, and occur mostly in limited word combinations (collocations) that impose a number of semantic restrictions. These rarely have direct equivalents in English and pose a serious problem even for advanced learners of German. A further interesting fact emerging from Fandrych's (2001, 2002, 2006) work on English and German verbs used in academic papers is the difference in the ways the research process is conceptualised in both cultural contexts. Whereas the German verbs tend to draw more strongly from the spatial and physical imagery and hence, conceptualise the research process as a kind of navigation in a multidimensional space, in English, there is a stronger focus on the aspects of seeing and showing. Such differences are a product of the historical development of national academic languages. Research into the historical process of the formation of academic lexis could contribute to a better understanding of the metaphorical character of academic language and cultural differences existing between academic German and English as well as other languages. However, there has been to-date very little research into this area, including in EAP.

Academic verbs were also recently examined by Meißner (2009). In contrast to previous studies, she adopted a corpus-linguistics approach to investigate the frequency and functions of academic verbs that have figurative meanings. She looked in particular at verbs that are formed 
by adding a prefix to the verbal base, which is, at the same, a commonly used verb in German such as gehen 'to go' or werfen 'to throw'. By analysing a large corpus of academic texts (2.2 million tokens), she demonstrated that figurative verbs constitute a large proportion of academic texts amounting to over $50 \%$ of total tokens. A subsequent qualitative examination revealed that these verbs can be divided into seven semantic categories: verbs of motion, posture, transfer, showing, grasping, connecting and separating, and perception. Furthermore, Meißner's analysis showed that in academic discourse, figurative verbs develop distinctive meanings and (metatextual) functions that differ from their uses in non-academic contexts. She concluded her study with some suggestions as to how figurative verbs could be treated in teaching academic German as a Foreign Language. Particular attention should be paid to the forms and the differences in functions that such verbs acquire in different contexts.

Heller (2006) examined comparatively some of the most typical collocations used in academic German and Italian. The starting point for her analysis was the observation that many typical word combinations of academic German may have literal equivalents in Italian and vice versa. On the surface, they seem to be similar. However, if one looks deeper into the meaning, it quickly becomes apparent that the supposed equivalents reflect only partial meanings and express different metaphorical dimensions. She illustrated this by analysing some of the collocations that seem particularly problematic for Italian students of German.

Starting from the assumption that semantics plays a crucial role in establishing and maintaining power relations, some scholars turned their attention towards investigations of the role lexis plays in knowledge construction, dissemination and in the establishment of academic fields of inquiry. With respect to this, lexis is seen as a means of imposing competing theories and interests in the academic struggle for recognition and resources. This often results in certain words and meanings becoming hegemonic buzzwords. Wengeler (2006) demonstrates this, for 
example, in his work on different shades of meanings of the frequently used terms discourse, mentality and culture in historical studies. Liebert's (2006) work on the establishment of the term Ozonloch 'hole in the ozone layer' in scientific discourse and Scherner's (2006) study on the use of the terms text, speech and discourse as competing terminologies in linguistics shed light on the powerful role of language in the formation, evaluation and dissemination of academic knowledge and questions the too easily assumed objectivity of research. Recently, there have been a number of studies examining lexis in new scientific fields such as biomedicine, genetics or nanotechnology and their reception in public discourse highlighting a number of controversies triggered by the use of certain terms (Felder 2006; Domasch 2007). For example, by analysing statements from a range of official medical sources related to the introduction of the preimplantation genetic diagnostics in Germany, Domasch (2007) demonstrated how certain nonmedical terms such as the verb verwerfen, literally 'dismiss', acquire new controversial meanings or are used in a euphemistic way.

\subsection{Pragmatic and textual aspects}

Most research on academic German has been underpinned by concepts and analytical tools developed within the tradition of functional pragmatics (e.g. Ehlich 1998; Redder 2008) and text linguistics (e.g. Brinker 2001) with considerable influences coming from the field of crosscultural rhetoric (Kaplan 1972) and, to some extent, genre analysis (Swales 1990). Each of these traditions contributed to the development of distinctive research interests. Whilst scholars working mainly within the functional-pragmatic framework focused on selected aspects of academic discourse such as discourse devices or selected functions, those influenced by the textlinguistic tradition examined text organisation and larger textual patterns. The latter often combined elements of text linguistics with the functional-pragmatic approach. This section is 
therefore divided into two parts; the first - micro-perspectives - focuses on research concerned with selected aspects of academic discourse, while the second - macro-perspectives - reviews studies focusing on larger textual aspects and genres.

\subsubsection{Micro perspectives}

This section will start by reviewing a study by Redder (2001) on modal verbs in German and English academic papers. Although Redder focuses on modal verbs, which, one could argue, is an area of morphology, her study looks at the issue in a broader context of academic argumentation and is therefore better placed in the section dedicated to pragmatic aspects. The starting point for her analysis is the observation that modality, but modal verbs in particular, play an important role in academic argumentation. Examining modal verbs in academic texts in English and German could therefore offer significant insights into the different strategies of argumentation adopted in the two academic cultures. She further argues that the German texts demonstrate a stronger preference for the hermeneutic tradition as evidenced by the emphasis placed on building up an understanding. In contrast, the English texts tend to follow the empirical and positivist tradition and hence, a greater focus on the deductive-descriptive ways of writing about research can be expected. This is an interesting observation, which was, to some extent, empirically verified in more recent research by Thielmann (2009). Redder's (2001) analysis has demonstrated that overall, modal verbs feature prominently in academic writing in German and English. Whereas there are some overlaps in terms of their use and functions, for example, in certain argumentative contexts between will and wollen 'to want/will', there are also significant differences. An interesting example here is the use of the English modal verb should, which seems to carry on much more of an argumentative potential than its German equivalent sollen. Redder's analysis highlights a number of interesting facts that have been examined in detail. 
However, it is, at the same time, based on a very small data set - only two texts from the same discipline were examined. It seems vital to verify some of the observations by analysing larger textual data and also in different disciplines.

Similar to EAP, there has been a considerable amount of literature on a variety of discourse devices. For example, Fandrych (2001) and Fandrych \& Graefen (2002) examined textcommenting devices in German and English. Text-commenting devices are defined as writers' comments on the text itself with the purpose of directing reader's attention to the text structure. By analysing a corpus of 19 research articles in German and 17 in English taken from a variety of academic disciplines, the authors identified different preferences in the use of such devices in both languages. While German authors tend to comment on the text structures at the micro-level, the English writers 'seem to prefer to imagine the text $[\ldots]$ as an already finished product and give an overview of its structure' (Fandrych \& Graefen 2002: 35). Moreover, the German text commenting devices make a greater use of modal verbs as well as deictic and para-deictic elements (in their generic meaning), whereas for the most part their English equivalents do without them. The results question some of the generalisations made in earlier research, particularly the assumed lack of reader-friendliness of German academic texts (Clyne 1987). It appears that German scholars also put a lot of effort into making their texts transparent to the reader. They do so by making a greater use of temporal and spatial deictic devices such as nun 'now', im folgenden 'as follows' that assist the reader in understanding the given text as an ongoing, chronological research process. This strategy seems to be less prominent in English texts as evidenced by a smaller number of such devices.

Illustrativa is another type of function typical of academic discourse. These are defined as metatextual expressions used for the purpose of demonstration and integration of examples and visual data into the text. In her study on illustrativa in academic German, Olszewska (2006) 
identified three major contexts of their use: structuring of the texts into smaller parts, argumentation and repetition, and interaction with the reader. The study revealed a large variety of such expressions. A comparison with other languages could yield further insights into the forms and functions of such devices across different academic traditions.

Siepmann's (2005) extensive corpus-based research into discourse markers in academic texts in English, German and French is another example of the comparative interest in GAP. The main aim of this study was to examine structural and functional differences in the use of multi-word discourse devices across the three languages. Siepmann (2005) looked specifically at the secondlevel discourse markers (SLDMs), which he defines as markers of medium frequency, composed of two or more words and which are fixed expressions or collocations. The first part of his research offers a comprehensive taxonomy of the structural and functional properties of the most frequently used SLDMs in all three languages. This is followed by a detailed contrastive analysis of three functional categories: exemplifiers, reformulators and inferrers. The results offer significant insights into the forms of SLDMS and point to possible translation equivalents in German, English and French. Overall, it seems that French contains the largest repertoire and the greatest variability of such devices. This is a sign of elegance from the point of view of the author - a rather aesthetic judgment, which seems to be at odds with the very comprehensive linguistic analysis provided. The second part of the study is concerned with lexical problems encountered by native speakers of German when writing academic English. It is based on quantitative and qualitative comparisons between native (English) and non-native texts. The analysis confirms some of the findings obtained in earlier research concerned with native vs. non-native performance (e.g. De Cock 1998; Granger 1998). German natives seem to rely more on first-level discourse markers; when they use SLDMs, the range and frequency of such devices are much lower. The study finishes with a number of useful suggestions as to how to improve the treatment 
of SLDMs in dictionaries. Siepmann's (2005) research offers comprehensive, cross-linguistic insights into the syntactic and pragmatic aspects of the medium-frequency discourse markers, and provides a number of implications for translators and scholars involved in teaching academic English, German and French. His detailed taxonomy of functional categories of SLDMs can be of value for researchers interested in discourse markers in other languages.

Influenced to some extent by EAP, and especially research by Salager-Meyer (1994) and Hyland (1998), some researchers began investigating the expressions of personal stance in academic German. Indicative here are two studies: a smaller piece of research by Steinhoff (2007a) on the use of the person pronoun ich 'I' and a larger comparative study on hedging devices, and the first person pronouns by Breitkopf (2005).

In German-speaking academic culture, there seems to be a tendency to see academic writing as a product of objective and dispassionate inquiry. Hence, it is often recommended to avoid expressions of personal stance, especially the use of the first person pronoun. The academic style should be rather impersonal, which in German can be achieved through the use of passive forms, reflexive verbs and nominalisations. The objectivity of research has been called into question at least since Karl Popper's philosophy of science and Kuhn's seminal work on 'The structure of scientific revolutions' (1962). Every scientific/ academic inquiry is a product of individual efforts and the avoidance of $i c h$ 'I' seems to be a rather LINGUISTIC I-PROHIBITION - ich-Verbot (Weinrich 1989), or even a kind of a repressive measure. Following the psychoanalytic theory of Freud, Kretzenbacher (1995) describes this rather strongly as ICH-TABOO 'I-taboo'. Given the polarised attitude to the use of ich 'I', Steinhoff (2007a) examined empirically whether such a taboo still exists and whether there are any disciplinary differences. To this effect, he analysed the use of $i c h$ in two corpora, the first consisting of 99 academic papers (expert writing) from three disciplines: linguistics, history and literary studies, and the second consisting of nearly 300 
student essays (novice writing) written at different stages of university education. Analysis of the expert writing revealed that the I-taboo is not as prevalent as assumed, though there seems to be considerable disciplinary influence. Academic writers in Linguistics and Literary Studies make a greater use of ich 'I' than those in History. The novice writing also tends to exhibit the same tendency. However, with the progression of studies, use of the first person pronoun diminishes.

The pervasiveness of the I-taboo was also refuted in a comparative study by Breitkopf (2005), who examined two features of personal stance in German and Russian academic papers from sociology: self-references (the first person pronoun in singular and plural) and hedging devices. Breitkopf's analysis, which is based on a larger data set (30 articles in German and 30 in Russian) provides more substantiated evidence for some cross-cultural differences and similarities in expressing personal stance. Both German and Russian authors use the first person pronouns considerably. At the same time, the German writers tend to use the first person pronoun in singular more frequently than Russian authors, who show a stronger preference for wir 'we' and use it in a wider context, for example, with a reference to the nation. The analysis of hedging devices points to a number of similarities. It seems that in both academic cultures, assertion is more prominent than the use of cautious language.

\subsubsection{Macro-perspectives}

As mentioned in section 3, advances in text linguistics and contrastive rhetoric wielded considerable influence on research in GAP. The trigger was a hypothesis proposed by Galtung (1985) about the existence of four major intellectual styles: teutonic, saxonic, gallic and nipponic. He argues that the typical feature of the teutonic style is a strong focus on theories and explanations, whereas the saxonic style tends to put more stress on empirical descriptions and data analysis. His hypothesis was not based on solid empirical evidence and it seems to be a 
collection of rather sweeping personal views on various discussion styles. Nevertheless, it triggered a strong research interest in cultural differences in the organisation of academic texts.

Particularly influential here was the contrastive research undertaken by Clyne $(1987,1991)$, who, by drawing on Kaplan (1972), claimed that the underlying feature of German academic writing is digressiveness (Clyne 1981). In contrast, English texts have a linear structure, which substantially assists the reader in understanding the academic content. Furthermore, German academic texts 'are more likely to be characterised by discontinuity' (Clyne 1987: 228) and include fewer advance organisers than academic texts in English. This all leads, in his view, to poorer readability of German texts; the reader has to make an extra effort to understand them. Consequently, German was described as a reader-responsible-language, whilst English was referred to as a writer-responsible-language (Hinds 1987). Drawing on Clyne's work, Eßer (1997) examined text functions, structure, content and style of German and Mexican student essays and dissertations. She found, for example, that Mexican texts include a range of expressions of personal stance and opinions - aspects that were absent in German writing. Similarly, Hufeisen (2002) compared English student essays with German written-up student presentations (verschriftliches Referat) and subsequently looked at German texts produced by Canadian students of German. She was able to identify a range of differences between the German and English texts at the level of text structure and organisation, especially in the use of connecting and cohesive devices. For example, repetition seems to be used more frequently in English than in German. Since the two studies were motivated by writing needs of non-native students of German, both authors offer a number of suggestions as to how cross-cultural differences in text organisation and structure could be treated in university teaching.

Following on from the cross-cultural research by Clyne and others, it has been widely assumed that German academic style is characterised by a stronger drive for confrontation and 
direct criticism manifested, for example, in the lesser use of downgrades and a higher amount of upgrades (Clyne 1987). Hutz (2001) examined this claim by analysing hedging in 30 academic reviews in English and 30 in German. His study demonstrates that criticism indeed takes up more space in German reviews and it is expressed in a more direct and confrontational way.

Studies conducted in the text-linguistic and cross-cultural tradition point to a number of differences between German and English (written) academic texts. However, at the same time, caution is needed when extrapolating the results. With the exception of Hutz (2001), Fandrych \& Graefen (2002) and Breitkopf (2005), most of the studies are based on a rather small data set, and in some cases only two texts. Given the small empirical base, the conclusions seem very strong. There is, at times, a tendency to broad-brush generalisations, especially when assuming a link between culture and writing style. As Fandrych \& Graefen (2002: 36) observe, many of the studies concerned with cross-cultural differences lack a concept of culture that 'could be said to be sufficiently theoretically developed.' There are substantial differences in the way culture is conceptualised across various speech communities. For example, the German concept of Kultur is not the same as the French civilisation or the English culture. This makes comparisons of the supposed culture norms rather difficult (Graefen 1997).

The developments in Text Linguistics and Genre Analysis triggered also a strong interest in academic genres, in German literature often referred to as academic TEXTSORTEN 'text types'. Analytical frameworks and typologies developed by Brinker (2001), Heinemann \& Viehweger (1991), Swales (1990) and Heinemann (2001) were particularly influential here. For example, Heinemann (2001) classifies all texts produced within the university context into three major types: theoretical, didactic and administrative. As in the case of EAP, mostly theoretical and didactic genres have been examined to date, notably wissenschaftlicher Artikel 'research paper' (e.g. Graefen 1997; Thielmann 2009), abstract (Kretzenbacher 1998b; Busch-Lauer 2007), 
Protokoll 'minutes' (Moll 2001), academic review (Ripfel 1998) and Seminararbeit 'student essay’ (Stezano Cotelo 2008; Prestin 2011).

By drawing on the concepts of the PROZEDUR 'procedure' and FELD 'field' developed within functional pragmatics, Graefen's (1997) book-length analysis of the genre research article focuses on forms and functions of deictic and phoric procedures. Whereas the former are understood as procedures that focus reader's attention by, for example, the use of the first person pronouns or adverbs of time and place, the latter refer mainly to anaphoric elements. Graefen's study has demonstrated that deictic elements are a prominent part of research articles as evidenced by their high frequency and variability. In contrast, anaphoric elements are less frequent. Both procedures play a significant role in the organisation of research articles, especially at the micro-level. They also help retain the information included in the text. In her concluding remarks, Graefen (1997) argues that both procedures assist the reader in navigating and understanding a given academic text, and in so doing, contribute to the reader-friendliness of German texts. She disputes Clyne's claim that the reader has to make an extra effort to understand German academic texts and argues that his conclusion is based on the examination of a limited number of linguistic features. However, she also points to the fact that German authors tend to consider experts as potential readers, whereas English-speaking authors often address their texts to a wider circle including experts and non-experts. This could explain some of the differences in the writing style, though more research is needed in order to verify this assumption.

Research articles are also the main focus in a recent comparative study by Thielmann (2009). Following from his previous research (Graefen \& Thielmann 2007), the main concern he addresses in his book-length study is the extent to which German and English differ in the realisation of three main functions: introducing research objectives, causal relations and naming procedures. To this effect, he examines in detail three areas: introductions, causal relations as 
exemplified by the use of the English conjunction because and its German equivalent weil, and parts of speech used to name new research findings. His analysis of German and English introductions reveals that the German texts seem to be less linear than their English counterparts. This seems to confirm the tendency established in previous research (Clyne 1987). However, this lack of linearity is a surface phenomenon. Although German introductions seem to make less use of advance organisers, each paragraph constitutes an element in a larger argumentative structure, which aims at establishing a common ground between the author and the reader. This often involves detailed explanations of main concepts and justifications for the importance of the study in question. Frequently, relevant social problems are brought into discussion too. In contrast, English introductions put a stronger emphasis on addressing the aims of research directly and the common ground between the author and the reader is often taken for granted. Thielmann (2009) refers to the style of German introductions as HERMENEUTIC argumentation based on a progressive development of understanding. Moreover, Thielmann's (2009) study also demonstrated that the two apparent translation equivalents because and weil are employed for different argumentative purposes in English and German academic writing. Finally, both languages seem to make use of different parts of speech when naming new facts and findings. Whereas German shows a preference for deverbal nouns, which put extra emphasis on the process, English texts exhibit a stronger preference for metaphorical expressions. All in all, Thielmann's (2009) research shows (1) the different ways in which knowledge is conceptualised in the two language cultures and (2) the different resources that both languages employ for the purpose of academic/scientific argumentation. He argues that having one dominant language of academic communication - English - would inevitably lead to the demise of the distinctive academic traditions in other cultural and language contexts. 
An important part of knowledge creation and dissemination is an expert critique of published research. In most branches of natural sciences and humanities this happens through the process of a written review, in German referred to as Rezension. The main aim of an academic review is to assess new knowledge published in book form. This should normally be undertaken by an expert in the field. The assessment criteria normally include (1) the contribution of the reviewed research to the established knowledge in the field, (2) the validity or suitability of the chosen method, and (3) clarity and logic of argumentation. Although the academic review should offer a fair and critical assessment with negative judgments if applicable, Ripfel (1998) notes that most of the reviews she analysed were, in fact, positive. This is an interesting claim that needs to be further corroborated in larger data sets and also across different cultural contexts.

Another form of academic critique frequently employed in the German-speaking academia is a Gutachten, which is perhaps best translated as an expert evaluation. Gutachten differs from a reference in that it is not a personal appraisal but an assessment of research a student or an academic has completed (e.g. MA-thesis) or intends to undertake (e.g. a PhD or book proposal). It is also different from a Rezension, as it is not a published text but a document used for internal academic purposes. Hoffmann (1998) analysed 100 academic Gutachten and identified two major macro-structures typical for this text type: type A, which follows the structure of the assessed research and comments on each chapter or section, and type $\mathrm{B}$, which focuses on overall strengths and weaknesses. Type B is less frequent than type A, which is, in Hoffman's (1998) view due to its rather elaborate character.

With the enormous increase in publications in recent times, there is a need for quicker navigation through the vast amount of research articles and books available. Abstracts play a particularly important role in this process. Compared to EAP, there has been less research on academic abstracts in the German-speaking context. This is perhaps due to the fact that the term 
abstract is a rather new addition to the German academic vocabulary. As Kretzenbacher (1998b) observes, there is still a lack of terminological clarity as to what a text type abstract is. In the German-speaking context, other terms are used synonymously such as Zusammenfassung 'summary' or Kurzreferat 'short presentation', although they do not necessarily mean the same thing. Based on his earlier research, Kretzenbacher (1998b) points to a large variety of texts that could be classified as abstract. A systematic treatment of German abstracts has been offered by Busch-Lauer (2007) who pointed to a range of functional and syntactic features of this text type. Given the prominence of abstracts in academic work nowadays, more research still needs to be done on the subject in the German-speaking context.

Apart from recapitulating text types, Kretzenbacher (1998b) distinguishes texts whose main function is to reconstruct events happening in academic settings. In German, this type of text is referred to as Protokoll, best translated as minutes. Protokoll is normally understood as a form of documentation of meetings, procedures or work, and is widely used in academic and nonacademic contexts. Kretzenbacher (1998b) divides Protokoll into two types:

Kommunikationsprotokoll 'communicative protocol' und Ereignisprotokoll 'event protocol'.

Whereas the former reconstructs the course of oral events such as lectures or meetings, the latter documents empirical procedures and experiments and it is, therefore, frequently employed in natural sciences, especially medicine and chemistry. The most extensive work conducted on protocols to date has been undertaken by Moll (2001). Since communicative protocols in form of lecture or seminar notes are an important part of university education, she looked at protocols written by students. Her study follows a discourse-analytical methodology and takes a comprehensive approach to investigate this particular text type. Moll (2001) is not only concerned with the product itself, but also with the process of writing protocols, especially with the strategies of knowledge reproduction. To this effect, she recorded a number of lectures and 
seminars and analysed notes completed by students during these 'events'. Her results demonstrate that students have considerable difficulties in writing appropriate protocols. They often focus on key facts only and omit many relevant interrelations or connections. Distinguishing relevant aspects from less important information seems particularly problematic. Moll (2001) offers a number of pedagogical suggestions to help students to better reproduce the knowledge conveyed in lectures and seminars.

Didactic text types, especially student essays, have recently become an important research area in GAP. Studies with a comparative focus were mentioned at the beginning of this section (Eßer 1997; Hufeisen 2002). Here, I will refer to three recently completed research projects that combine elements of the text-linguistic and functional-pragmatic approach. The first one is a study by Stezano Cotelo (2008) who looked at strategies of how foreign students incorporate claims reported in research literature into their essays. She analysed literature references in a corpus comprising of 39 student essays and compared them with their original sources. Overall, she identified three main strategies: 1) citations, 2) citations together with rephrasing, and 3) rephrasing combined with summarising. Citations were, by far, the most frequent form of literature reference. Less frequent was the third strategy combining rephrasing with summarising and it was rather typical for more advanced students. Stezano Cotelo (2008) also pointed to a number of difficulties foreign students experience when referring to research literature. For example, they have problems with recognising criticism or play down critical argumentation. Besides, when embedding claims from secondary sources, they use a lesser range of lexical expressions and overall, their writing resembles more journalistic than academic style.

The journalistic style of student academic writing was also one of the aspects discussed in a recent work by Steinhoff (2007b). His main aim was to investigate the development of academic literacy and the differences between novice and expert academic writing. By analysing and 
comparing three large corpora (student essays vs. research papers vs. journalistic texts), he identified three stages in the development of academic writing: transposition, transformation and contextual adequacy. Steinhoff (2007b) was able to show some of the lexico-grammatical patterns typical for each stage. It is in the first stage that novice writing bears a stronger resemblance to journalistic style.

The most recent piece of research concerned with Seminararbeit 'student essay' is a study by Prestin (2011). By taking the research article as a model for student academic writing, she offers a comparative analysis of the two text types. Her analysis focuses especially on the introductions and the strategies of introducing and justifying research objectives. To this effect, she examined in detail the first paragraphs of 71 student essays (native speakers of German) and 44 research papers taken from the discipline of Germanistik 'German Studies' including Linguistics and Literary Studies. Prestin (2011) identified overall six types of strategies used to introduce research objectives: Ankündigen 'explicit announcement of research aims', Bewerten 'evaluation', Assertieren 'assertion', Fragen 'question', Zitieren 'citation' and Berichten/Erzählen 'narration'. The analysis revealed some quantitative differences in the use of introducing strategies in expert and novice writers. Whereas expert academics show a preference for assessment, assertion and citation, students tend to explicitly state their research objectives. Overall, Prestin (2011) demonstrated that the strategy used to introduce one's own research has an impact on the illocutionary and propositional structure of the whole text. Students are often not aware of the significance of introductions (also from the point of view of assessment) and some make a number of functional mistakes, for example, using personal narration where it is not appropriate. Strategies for writing successful introductions therefore need to be more strongly considered, for example, in writing courses that ought to be offered at the beginning of university education. 
In the German-speaking context there is also a strong research tradition concerned with analysis of academic language in various domains and disciplines (Hoffmann et al. 1998). For reasons of space, a detailed summary of research conducted in this area has been left out from this overview. For those who are interested, a comprehensive summary of research on the language of engineering is offered by Heine (2010). Reuter (2010) provides an overview of studies concerned with the language of economics and tourism, while Ylönen (2010) looks at the language of medicine. Kretzenbacher (2010) summarises the features of academic German in humanities and social sciences, and Fluck (2010) in natural sciences.

\subsection{Spoken academic German}

As in EAP, the most extensively examined spoken genre in GAP has been, to date, the academic lecture (Vorlesung) (Sucharowski 2001; Grütz 2002). Grütz (2002) points to the fact that academic lecture cannot be classified solely by the traditional categorisation of genres into spoken and written, as it combines a number of elements from both registers. By drawing on the theoretical framework for the analysis of genres proposed by Koch \& Oesterreicher (1985), she points out that lectures are, in terms of the medium, a spoken genre. However, at the same time it is also a conceptually written text type, since it is often based on a script prepared in advance. This has some advantages and disadvantages for comprehension, especially for non-native students. On the one hand, since lectures are similar to academic papers, they will follow a specific structure. On the other hand, they normally convey densely packed information, which could be difficult to understand. However, lectures also contain a number of elements typical of spoken conversations, such as repetitions, paraphrases, discourse markers and metacommunicative devices such as summarisers, concluders, enumerators and attitude markers. Such 
elements facilitate comprehension and this is why Grütz (2002) calls for the inclusion of these devices in teaching GAP.

Also Jasny (2001) used transcripts of academic lectures to examine a complex syntactical structure typical for German, namely the verbal bracket. The term verbal bracket refers to a syntactical construction, in which most elements of the clause are 'sandwiched between the various parts of the verb' (Durrell 2002: 470). In spoken German, previous research estimated the average number of elements in the bracket at 2.8 words (Thurmair 1991). A particular form of the verbal bracket is a lexical bracket created through the use of a separable verb, where most of the elements of the clause are placed between the main verb, which is normally the second element in the sentence, and its prefix located at the end. Because of the split nature of the construction, some linguists claim that the use of the lexical verbal bracket is risky and there may be a tendency to avoid it altogether by replacing the separable verb with a non-separable one. Jasny (2001) investigates this claim by examining the use and length of lexical verbal brackets with separable verbs in 26 academic lectures from a variety of academic disciplines. She found that lecturers make a frequent use of the verbal bracket with a separable verb, which counteracts the claim of the riskiness of such constructions. Interestingly however, her research showed that many of the brackets were used in a rather formulaic type of constructions that often function as discourse structuring devices. Furthermore, the average length of the brackets was 3.5 words (4.1 in humanities and 3.0 in natural sciences) - a result which does not differ substantially from the previous estimate for everyday spoken language and which points to the close links between the two registers. In her concluding remarks, Jasny (2001) discusses some ways in which the lexical verbal bracket could be treated in teaching German as a Foreign Language in order to foster the development of better academic listening skills. This part is, unfortunately, rather general and no concrete teaching examples are demonstrated. 
There has also been a fair amount of comparative research on spoken academic discourse with lectures and conference presentations being mostly investigated. For example, Schleef (2009) examined functions of conversational support and a degree of formality in Canadian and German lectures and interactional classes. He looked, in particular, at certain types of question tags, questions, structural markers, backchannel signals, and turn-initial response tokens. Schleef's analysis revealed considerable differences between German and Canadian academic speech styles. The German spoken academic style seems to exhibit a higher degree of formality, as evidenced by the frequent use of group vocatives and read-out speech. In contrast, Canadians seem to give more support to interactions through a greater use of questions and progression checks.

Conference presentations were also the genre examined comparatively by Ventola (2007). She looked at conference papers given by English- and German-speaking academics. The starting point for her analysis was the observation that at most international conferences, English is nowadays the dominant language, which sometimes leads non-English researchers to feel inadequate or inferior because they lack the native language skills. Ventola (2007) argues that the success of a conference presentation cannot be judged solely on lexical appropriateness or grammatical and phonetic accuracy. There are also other important aspects such as engagement with the audience that need to be considered. Unfortunately, there are virtually no assessment criteria for successful conference presentations and in this area, novice, native and non-native researchers are often left to their own devices. By analysing transcripts of four conference presentations given in English by two native speakers of English (one British and one American) and two German speakers, she could identify some cross-cultural differences in the style of presenting. For example, the German speakers tended to read out some parts of their presentations and used the pronoun $I$ less frequently than their English counterparts. The British 
speaker seemed to engage more with the audience than the others. Ventola (2007) offers some interesting insights into the styles of conference presentations. However, as with other crosscultural studies, the observations are difficult to generalise and need to be verified in larger data sets.

The most recent comparative research on spoken academic discourse is a study by Reershemius (2012), who looked at functions of humour in German and English conference presentations. Her research demonstrated that in this context, humour is used predominantly as an expression of discourse reflexivity. She also identified some cross-cultural differences; it seems that researchers educated in the German academic context exhibit a more formal style of presenting (often read-out speech, see also Schleef 2009) and use humour less than those raised in the Anglophone university system. Alongside linguistic and educational background, the professional experience and the status of an expert also plays a role in the use of humour. Reershemius' (2012) study is part of research activities carried out within the international project Gesprochene Wissenschaftssprache Kontrastiv (GeWiss) 'Spoken Academic Language in Contrast'. The main aim of the project is to compare spoken academic discourse across three languages English, German and Polish (Fandrych, Meißner \& Slavcheva 2012). To this effect, a range of spoken academic genres were collected and compiled in three large corpora. The GeWiss corpus, which consists of 1.2 million tokens, is now available online and it is free to use for research purposes ${ }^{3}$. The GeWiss corpus complements the already existing resources such as the Michigan Corpus of Spoken Academic English (MICASE) and the British Academic Spoken English Corpus (BASE).

Alongside Seminararbeit 'student essay' discussed above, Referate 'student presentations' are an important part of university education in the German-speaking context, especially in the humanities. Often at the beginning of a module, the lecturer will circulate a list of topics, which 
students then select for their presentations. Referate are normally given at the beginning of a seminar with the view to introduce the participants to the given topic/area. They can be given individually or by a group of students. In a recent study, Guckelsberger (2005) analysed 25 student presentations given in humanities. By drawing on the discourse-analytical methodology, she demonstrated that Referate 'student presentations' can be highly dialogical in nature with a number of turns taken by the lecturer and the student-audience. The involvement of the lecturer seems to be particularly high, when the presentation is seen as deficient and not well-prepared. Guckelsberger (2005) also focused on strategies for how students convey relevant knowledge in their presentations. She identified two underlying patterns: a patchwork-strategy, when a student relies heavily on the wording of the original sources and presents his or her topic almost verbatim, and a free presentation, which is based on bullet points and presented freely. The latter seems to be more successful in conveying the relevant knowledge. On the basis of her analysis, Guckelsberger (2005) outlines examples of pedagogical materials for use in university writing courses.

Oral examination is also an inherent part of university education in the German-speaking context. As a method of assessment, it seems to be of much higher importance than in Anglophone academia (Schleef 2009). For example, the final exam (Abschlussprüfung) is normally an oral exam. The first insights into this genre were offered by Meer $(1998,2000)$. By drawing on the Foucauldian perspective on power and knowledge, and the methods of conversation analysis, she scrutinised 20 oral examinations. Her analysis demonstrated that despite their main assessment function, oral examinations can be a site of confrontations or even Machtkämpfe 'power struggles', especially when the examiner is confronted with deficits in students' knowledge. Meer (1998) showed also examples of a successful communicative behaviour, which was characterised by a less hierarchical structure and a coherent talk on both 
sides - the examiner and the examinee. On the basis of her analysis, Meer (1998, 2000) outlines a number of strategies that both examiners and examinees could utilise in order for the examinees to improve their performance during oral exams.

\section{GAP and teaching academic writing}

The aim of this section is to outline the recent developments in the area of teaching academic writing in the German-speaking context. Research on academic writing has been largely influenced by the German tradition of Schreibforschung 'writing research' and it would require an article on its own to summarise the developments in this area. In this section, I will only focus on the influences that the research discussed above has had on the creation of new practical models and approaches to teaching academic writing.

From the outset, studies concerned with academic German were driven by pedagogical needs. One of the main objectives was to describe features and patterns of academic German in order to help students develop better academic reading and writing skills. The pedagogical developments in GAP paralleled those in EAP (e.g. Paltridge 2004). In the early, lexical and structuralist phase, a number of specialist dictionaries and teaching books were created focusing mainly on terminology and lexis (e.g. Rogalla 1986; Schade 2009). Although heavily based on grammatical exercises, Schade's (2009) Einführung in die deutsche Sprache der Wissenschaften still enjoys great popularity; it is currently available in its $13^{\text {th }}$ edition.

Advances in functional pragmatics and text linguistics shifted the focus to rhetorical functions and stylistic devices as well as text organisation. Most of the studies in this area offer a number of pedagogical implications. A good example here is the recent volume edited by Ehlich \& Steets (2003), though most of the papers are still quite theoretical in nature and offer few practical solutions. 
Some practical suggestions are included in the work by Graefen (1999, 2009). Inspired by the concept of alltägliche Wissenschaftssprache 'ordinary academic language' and her own research on the subject, Graefen $(1999,2009)$ proposes a number of suggestions as to how improve teaching academic lexis. She recommends a compilation of lists with the common ordinary nouns, verbs and adjectives together with their most frequent combinations. Some examples are demonstrated by looking at the use of the noun Analyse 'analysis' and Aspekt 'aspect' (Graefen 1999). But lists are not enough. It is also critical to raise students' awareness of the differences in the use of ordinary academic lexis in academic discourse as opposed to everyday speech and to highlight its metaphorical character (Graefen 2009). This is especially important for non-native students who seem to experience considerable difficulties in understanding metaphoricity of academic vocabulary (Ehlich 1999). Recently, Graefen's approach to academic lexis inspired a new textbook dedicated to academic writing (Graefen \& Moll 2011). It is the first comprehensive teaching material that focuses on the most frequent academic vocabulary and word combinations (collocations) including idiomatic and metaphorical expressions. It contains a range of exercises as well as concise explanations about the use and functions of a variety of lexical devices typical of the organisation of German academic texts such as pronouns, connectors, articles and adverbials. Moreover, the publication includes exercises on argumentation strategies and is solely based on authentic material.

Other recent book publications that focus on teaching and learning academic writing include Bünting, Bitterlich \& Pospiech (2000), Starke \& Zuchewicz (2003) and Mehlhorn (2005). The publication by Bünting et al. (2000) focuses on a range of academic text types such as lecture notes, exposé and Abschlussarbeit (final dissertation). Particularly useful is the discussion of the different stages of writing including pre-and post-writing activities. The book also offers a number of practical tips on how to structure an academic text and develop proper argumentation. 
This book is particularly useful for native speakers of German studying humanities. The two other publications are directed at non-native students. Similar to Bünting et al. (2000), Starke \& Zuchewicz (2003) offer insights into the writing process and products, and include a number of good and bad examples of selected text passages. However, the publication is still very general and the specific needs of non-native speakers especially in the area of academic vocabulary have not been addressed comprehensively. Besides, as with other similar publications, this book is most suitable for students in the humanities, especially Germanistik 'German Studies'. Mehlhorn's (2005) book is based on the concept of Lernberatung, which has recently become popular in German academia. In this context, the term normally refers to a personalised form of academic guidance; many universities in Germany have established Sprachzentren 'language centres', where a dedicated member of staff can offer personalised assistance to those with individual learning difficulties including writing. The book by Mehlhorn (2005) goes beyond teaching academic writing skills. It is designed as a resource for those who want to help nonnative students integrate better into the German-speaking academic context. It is divided into two parts; the first contains materials that focus on a range of communicative events that can be encountered in the German-speaking academia including oral events such as office hours or presentations, and written tasks such as emails and student essay. The second part focuses on strategies to foster learner autonomy in academic contexts. Overall, this is a resourceful book with many practical suggestions and examples of texts and lexical phrases (supplementary material also available on a $C D$ ) to be directly used in a teaching context. It is designed with the view to help non-native students in Germany. Students studying German Studies outside the German-speaking countries may find it less beneficial.

Recently, some web-based projects have also been created to teach academic writing and speaking skills. A comprehensive, multimedia online project is the EUROMOBIL programme, 
which aims to foster student mobility and prepare foreign students for their Year Abroad in a number of European countries, including the UK and Germany amongst others. ${ }^{4}$ Self-learning materials for advanced learners focus on communicative events experienced in the university context, for example oral examinations, and are based on audio-visual resources (Ylönen 2006).

Overall, it can be said that there is a great awareness of the need to develop better resources for teaching academic writing and speaking, for both native and non-native students. At the same time, there is still little material available that addresses the specific language needs of non-native speakers, especially in the area of academic vocabulary. Recently, there have been some developments attempting to integrate corpus-based techniques to teaching academic vocabulary, but this strand is still in its infancy (Jaworska 2011).

\section{Research perspectives for GAP and EAP}

For reasons of space, not all studies could be considered in this overview. The selection includes primarily empirical research, which is indicative of the dominant research traditions and interests that GAP scholars have pursued since the late 1990s. Research concerned with EAP conducted in the German-speaking countries has been excluded from this overview.

Despite the lesser significance of German as an academic language in the global academic community, GAP has developed into a vibrant research field covering a wide range of topics and issues. As in EAP, there is a substantial body of research concerned with micro-features of academic discourse (academic lexis, personal stance and a range of discourse devices) as well as larger textual aspects such as text structure, text organisation and a variety of academic genres including theoretical, didactical and administrative text types. Many of the studies reviewed above have a cross-cultural and comparative focus and despite certain limitations, shed light on a number of differences and similarities between German academic discourse and its English, 
Spanish, Russian or French counterparts. Moreover, it is particularly encouraging to see the growing interest in spoken academic language - an area, which has been for a long time marginalised in both EAP and GAP.

The range of topics and issues covered in GAP largely match research undertaken in EAP. At the same time, the amount of EAP research offers a number of ideas that should be addressed in GAP. Three issues spring immediately to mind: the use of corpora, student writing (especially the difference between the expert vs. novice writing) and cross-cultural comparisons with languages other than Indo-European.

Over the last 10 years or so, there has been a surge of corpus-based and corpus-driven EAP research providing empirical evidence for the frequency, use and functions of many lexical and grammatical features of academic discourse that are otherwise difficult to observe (e.g. Granger 1998; Coxhead 2000; Biber et al. 2004; Hyland 2008). As a by product, the EAP community now has at its disposal large corpora of academic English covering a wide range of disciplines, text types and registers (Krishnamurthy \& Kosem 2007). Many of them are freely available to EAP researchers. Such developments need to be paralleled in GAP. While many of the studies reviewed above provide significant insights into the properties of German academic discourse, most are based on a small sample of texts and the findings need to be attested in larger data sets. This seems to be especially relevant for studies concerned with cross-cultural differences. However, the difficulty is that there are very few corpus resources available and if a GAPresearcher is interested in pursuing corpus research, he or she will have to rely on his or her own collection. Compiling a corpus can be a time-consuming activity and may discourage many from undertaking corpus research. An important step in this direction is the aforementioned GeWiss project, which offers corpora of spoken academic German including native and non-native data. 
It would also be beneficial to the GAP community to have a freely available corpus of written academic German comprising disciplinary and genre variation.

The corpus research in EAP has also had a beneficial impact on the development of pedagogical materials, especially for teaching academic vocabulary (Ellis, Simpson-Vlach \& Maynard 2008). For example, EAP curricula have the advantage of drawing on the Academic Word List (Coxhead 2000), the Academic Keyword List (Paquot 2010), and the Academic Formula List (Simpson-Vlach \& Ellis 2010). Teachers of German in academic contexts find little support in this area, as materials addressing lexical features of academic German are scarce or not necessarily based on empirical, frequency-based evidence.

The second issue concerns the area of student writing. Given that academic writing is key to success in university education and at the same especially difficult for students (both native and non-native), it is encouraging to see the growing interest in texts produced by undergraduates. However, as compared with EAP, there are still a number of aspects that should be further examined. First and foremost, most research in this area in GAP has focused on student essays produced in the humanities, while other disciplines have been largely disregarded. Given that Business \& Management, Engineering, Law and Medicine are the most popular subjects with the highest number of students, native and non-native (Statistisches Bundesamt 2012), more research is needed into the genres required by these disciplines, also beyond academia in professional settings. Moreover, most GAP research concerned with student writing takes as a 'role model' research papers submitted by academics to professional journals. Given that only a minimal proportion of undergraduate students will eventually pursue an academic career, the research paper as a pedagogical standard is arguably a rather idealised model that only very few could follow. Successful novice writing could be a better benchmark for student text production. Furthermore, more research is needed into the criteria of assessment, also across academic 
disciplines, and including the issue of citation practices and plagiarism. These areas have been extensively examined in EAP. Indicative of the work on student writing across disciplines is the recent publication by Nesi \& Gardner (2012), which is based on empirical insights from the largest corpus of student writing, the British Academic Written English (BAWE) corpus. Plagiarism has also received considerable attention in EAP (e.g. Canagarajah 2002b; SutherlandSmith 2005). This research demonstrated that plagiarism is a complex issue and many students have difficulties in distinguishing between textual borrowing and coping text passages without acknowledging the sources. Some cross-cultural differences may have an impact on plagiarism too. Similar research developments are highly desirable for GAP. The issue of plagiarism needs particular attention. Recently, this topic stirred public debates in Germany, when it was revealed that some prominent political and academic figures had plagiarised parts of their doctoral theses or books.

As demonstrated above, there have been a number of studies comparing features of German academic language with other academic languages, mostly of Indo-European origin. Given the growing number of foreign students whose L1 is Turkish, Chinese or Arabic, comparisons with these languages could shed light on the different conventions underlying academic discourse in contexts other than (Western) European. They could also explain some of the difficulties faced by L1 Turkish, Chinese or Arabic students when studying in a German-speaking context. EAP has already seen a number of studies comparing academic English with academic Chinese and Arabic; these have been complemented by research concerned with the academic English produced by these speakers (e.g. Khuwaileh \& Al Shoumali 2000; Hinkel 2004; Chen \& Baker 2010; Hu \& Cao 2011). Similar research is also needed in the GAP context.

Over the last 20 years, EAP has grown to become an independent academic field of linguistic inquiry with a wide scope of research interests, its own journal and a solid body of knowledge. 
Although GAP is, by far, a much smaller discipline, it nevertheless can offer some inspirations for EAP researchers. When we look at current EAP research, it quickly becomes apparent that most studies are preoccupied with quantitative analysis, and particularly that which shows the distribution of selected language features across large, automatically-retrieved data sets (corpora). Some qualitative insights are given, but these are mostly reduced to a few concordance lines. While frequency-based analyses are certainly representative and highlight many facets of academic discourse that run counter to intuition, there are also some limitations. Corpus-based or corpus-driven studies equate frequency with saliency and importance. While frequent aspects are indeed essential, there are also many less frequent but equally important features that a corpus analysis may omit. The main problem seems to be the insufficient way of addressing diversity at the functional level: there are many ways of expressing a function, e.g. criticism and unless a corpus has been pragmatically annotated, it is rather difficult to retrieve automatically the variety of lexical means expressing a particular function. A qualitative analysis can be here of more help. The discourse-analytical approach as developed within the school of Functional Pragmatics and adopted in many studies reviewed above has offered insights into the variety of pragmatic strategies that an automated corpus analysis would not reveal. A fine-grained qualitative analysis would certainly complement many of the quantitative findings of EAP research. Moreover, the concept of alltägliche Wissenschaftssprache 'ordinary academic language' proposed by Ehlich (1993) and examined in a number of studies discussed above could offer a new perspective on lexical studies in EAP that so far have been dominated by the examination of automatically retrieved strings of words.

Studies focusing on semantic features of specific lexis in academic/scientific discourse mentioned above combine linguistic approaches with critical theories developed by Jürgen Habermas, Michel Foucault and Pierre Bourdieu. In so doing, they complement the purely 
linguistic analysis by offering a critical and sociological perspective on the process of knowledge creation and dissemination. In many ways, they shed light on power relations and competing interests which underlie this process. This is a dimension, which, to date, has not been much considered in EAP and the sociological tradition could be perhaps of some influence here. Related to this is the issue of institutional and historical processes involved in the production and dissemination of academic discourse. Many of the studies discussed above offer a detailed analysis of contextual and historical aspects that led to the establishment of certain discursive practices in academic contexts. This has increased our understanding of the evolution of academic discourse and the interdependence of language, institution and discipline. In contrast, many EAP studies seem to be decontextualised and the historical dimension is almost absent.

There are also many areas that both fields should address. Given the significance of oral communication in academic contexts, there is a need for more research into spoken academic discourse including genres other than lectures or conference presentations and across different disciplines, and languages. Since most spoken 'events' in academia are, these days, supported by the use of audio-visual tools, it also seems indicative to examine the impact of technology on presentational skills and knowledge reception. A multi-modal analysis based on large data sets could offer significant insights here (cf. Lobin 2009). Another area which is in need of attention is the use of social media for academic purposes. There is evidence to suggest that students and scholars are increasingly employing social networks such as Twitter and Facebook to acquire and share academic knowledge. However, the impact of these new media on the production and dissemination of academic knowledge is still largely unknown. It would be interesting to investigate what kind of academic discourse practices emerge in this sphere. Finally, most (Western) universities today attract a high number of foreign students from various educational, linguistic and cultural backgrounds. Universities have increasingly become multilingual sites 
where different academic traditions interact posing a number of challenges. More research is needed into this academic multilingualism and multiculturalism, and the potentials it offers for creative thought and innovation.

The last issue which must be addressed is how to make scholarship on academic discourse produced in and on languages other than English widely available to the community of EAP researchers. Most would probably suggest translation into English is the simplest solution. However, the case is more complicated and the example of comparative research on English and German introductions by Thielmann (2009) demonstrates this well. If a German-speaking scholar wants to be understood in the English academic community, his or her text would need to be translated by adopting the English discursive norms. Otherwise, an English-speaking scholar may be rather puzzled if confronted with a more literal translation. However, this would involve the process of creating a new text from which the discursive tradition of German scholarship would evaporate. This problem has recently been investigated in translation studies, where the term EPISTEMICIDE is used to refer to an extinction of distinctive epistemological traditions through the process of translation (Bennett 2007). It seems that translation is not the most appropriate solution after all. So, is there any other way which could assist the exchange of information between scholars of different languages? I would like to answer this question by pointing to a statement made by the translator Christian Lenhardt who embarked on translating into English the work by the famous German critical theorist Theodor W. Adorno. He became aware of the inadequacy of his own translation and arrived at the conclusion that if the readers are seriously interested in Adorno's work they should better start learning German (Lenhardt 1986). ${ }^{5}$ If truly constructive intercultural exchanges were to take place in academic community worldwide, then knowledge of foreign languages amongst the Anglophone scholars seems indispensable. I wish 
there was more support and enthusiasm for learning foreign languages in the English-speaking academia.

\section{Acknowledgements}

I would like to thank the four anonymous reviewers for their constructive and very helpful comments and corrections in the earlier versions of the manuscript.

\section{9, Bibliography}

Given space limitations, titles are given in the original language(s) only. Readers interested in their English translations should contact the author at

Ammon, U. (1998). Ist Deutsch noch internationale Wissenschaftssprache? Berlin: de Gruyter.

Ammon, U. (2001). English as a future language of teaching at German universities? A question of difficult consequences posed by the decline of German as a language of science. In U. Ammon (ed.), The dominance of English as a language of science. Effects on other languages and language communities. Berlin: de Gruyter, 343-362.

Ammon, U. (2004). German as an international language of the sciences - recent past and present. In Gardt \& Hüppauf (eds.), 157-172.

Auer, P. \& H. Baßler (eds.) (2007). Reden und Schreiben in der Wissenschaft. Frankfurt am Main: Campus.

Beaugrande, R \& W. Dressler (1981). Introduction to text linguistics. London: Longman. Beneš, E. (1966). Syntaktische Besonderheiten der deutschen wissenschaftlichen Fachsprache. Deutsch als Fremdsprache 3, 26-36. 
Beneš, E. (1981). Die formale Struktur der wissenschaftlichen Fachsprachen in syntaktischer Sicht. In Th. Bungarten (ed.), Wissenschaftssprache. Beiträge zur Methodologie, theoretischen Fundierung und Deskription. München: Fink, 185-212.

Benesch, S. (2001). Critical English for academic purposes. Theory, politics and practices. Mahwah, NJ: Lawrence Erlbaum.

Bennett, K. (2007). Epistemicide! The tale of a predatory discourse. The Translator 13.2, 151169.

Biber, D., S. Conrad \& V. Cortes (2004). If you look at..: Lexical bundles in university teaching and textbooks. Applied Linguistics 25.3, 371-405.

Blommaert, J. (2005). Discourse. Cambridge: Cambridge University Press.

Breitkopf, A. (2005). Wissenschaftsstile im Vergleich: Subjektivität in deutschen und russischen Zeitschriftenartikeln der Soziologie. Freiburg: Rombach.

Brinker, K. (1983). Textfunktionen. Ansätze zu ihrer Beschreibung. Zeitschrift für germanistische Linguistik 11, 127-148.

Brinker, K. (2001). Linguistische Textanalyse (5th edn.). Berlin: Schmidt.

Brinker, K., G. Antos \& W. Heinemann (eds.) (2001). Text- und Gesprächslinguistik. Ein internationales Handbuch zeitgenössischer Forschung. Berlin: de Gruyter.

Bünting, K., A.Bitterlich \& U. Pospiech (2000). Schreiben im Studium-mit Erfolg. Ein Leitfaden. Berlin, Cornelsen Scriptor.

Busch-Lauer, I. A. (2007). Abstracts. In Auer \& Baßler (eds.), 99-114.

Canagarajah, A. S. (2002a). A geopolitics of academic writing. Pittsburgh: University of Pittsburgh Press.

Canagarajah, A. S. (2002b). Critical academic writing and multilingual students. Ann Arbor: University of Michigan Press. 
Chen, Y. H. \& P. Baker (2010). Lexical bundles in L1 and L2 academic writing. Language Learning \& Technology 14.2, 30-49.

Clyne, M. \& H. Kreutz (1987). The nature and function of digression and other discourse structure phenomena in academic German. Working Papers in Migrant and Intercultural Studies 8, 1-22.

Clyne, M. (1981). Cultural and discourse structure. Journal of Pragmatics 5, 61-66.

Clyne, M. (1987). Cultural differences in the organization of academic texts. Journal of Pragmatics 11, 211-247.

Clyne, M. (1991). The sociocultural dimension: The dilemma of the German-speaking scholar. In Schröder (ed.), 49-67.

Coleman, J. A. (2004). Modern languages in British universities. Past and present. Arts \& Humanities in Higher Education 3.2, 147-162.

Coleman, J. A. (2006). English-medium teaching in European higher education. Language Teaching 39.1, 1-14.

Coulthard, M. (1977). An introduction to discourse analysis. London: Longman.

Coxhead, A. (2000). A new academic word list. TESOL Quarterly 34.2, 213-38.

Crystal, D. (2004). The past, present and future of world English. In Gardt \& Hüppauf (eds.), 2746.

De Cock, S. (1998). A recurrent word combination approach to the study of formulae in the speech of native and non-native speakers of English. International Journal of Corpus Linguistics 3.1, 59-80.

Domasch, S. (2007). Biomedizin als sprachliche Kontroverse. Berlin: de Gruyter.

Dressler, W. (1983). Textuelle Kohäsionsverfahren in der Wissenschaftssprache - eine funktionelle Ableitung. Fachsprache 5, 51-57. 
Durrell, M. (2002). Hammer's German grammar and usage (4th edn.). London: Arnold.

Duszak, A. (ed.) (1997). Culture and styles of academic discourse. Berlin: de Gruyter.

Ehlich K. \& D. Heller (eds.) (2006). Die Wissenschaft und ihre Sprachen. Frankfurt am Main: Peter Lang.

Ehlich, K. \& A. Steets (eds.) (2003). Wissenschaftlich schreiben - lehren und lernen. Berlin: de Gruyter.

Ehlich, K. (1993). Deutsch als fremde Wissenschaftssprache. Jahrbuch Deutsch als Fremdsprache 19, 13-42.

Ehlich, K. (1995). Die Lehre der deutschen Wissenschaftssprache: sprachliche Strukturen, didaktische Desiderate. In Kretzenbacher \& Weinrich (eds.), 325-352.

Ehlich, K. (1998). Funktionale Pragmatik - Terme, Themen und Methoden. Deutschunterricht in Japan 4.98, 4-24.

Ehlich, K. (1999). Alltägliche Wissenschaftssprache. Info DaF 26.1, 3-24.

Ehlich, K. (2000). Deutsch als Wissenschaftssprache für das 21. Jahrhundert. German as a Foreign Language 1, http://www.gfl-journal.de/1-2000/ehlich.html.

Ehlich, K. (2006). Mehrsprachigkeit in der Wissenschaftskommunikation - Illusion oder Notwendigkeit? In Ehlich \& Heller (eds.), 17-38.

Ellis, N. C., R. Simpson-Vlach \& C. Maynard. (2008). Formulaic language in native and second language speakers: psycholinguistics, corpus linguistics, and TESOL. TESOL Quarterly 42.3, $375-96$.

Erk, H. (1972, 1975, 1982). Zur Lexik wissenschaftlicher Fachtexte. 4 Volumes. München: Hueber. 
Eßer, R. (1997). Etwas ist mir geheim geblieben am deutschen Referat. Kulturelle Geprägtheit wissenschaftlicher Textproduktion und ihre Konsequenzen für den universitären Unterricht von Deutsch als Fremdsprache. München: Iudicium.

Fandrych, Ch. \& B. Sedlaczek (2012). 'I need German in my life' - Eine empirische Studie zur Sprachsituation in englischsprachigen Studiengängen in Deutschland. Tübingen:

Stauffenburg.

Fandrych, Ch. \& G. Graefen (2002). Text-commenting devices in German and English academic articles. Multilingua 21, 17-43.

Fandrych, Ch. \& G. Graefen (2010). Wissenschafts- und Studiensprache Deutsch. In Krumm et al. (eds.), 509-517.

Fandrych, Ch. (2001). 'Dazu soll später noch mehr gesagt werden': Lexikalische Aspekte von Textkommentaren in englischen und deutschen wissenschaftlichen Artikeln. In M. Davis, J. Flood \& D. Yeandle (eds.), Proper words in proper places: Studies in lexicology and lexicography in honour of William. Stuttgart: Heinz, 375-398.

Fandrych, Ch. (2002). Herausarbeiten vs. illustrate: Kontraste bei der Versprachlichung von Sprechhandlungen in der englischen und deutschen Wissenschaftssprache. In K. Ehlich (ed.), Mehrsprachige Wissenschaft - europäische Perspektiven. München: Institut für Deutsch als Fremdsprache/Transnationale Germanistik, http://www.euro-sprachenjahr.de.

Fandrych, Ch. (2006). Bildhaftigkeit und Formelhaftigkeit in der allgemeinen Wissenschaftssprache als Herausforderung für Deutsch als Fremdsprache. In Ehlich \& Heller (eds.), 39-61.

Fandrych, Ch., C. Meißner \& A. Slavcheva (2012). The GeWiss Corpus. Comparing Spoken Academic German, English and Polish. In Th. Schmidt \& K. Wörner (eds.), Multilingual corpora and multilingual corpus analysis. Amsterdam: Benjamins, 319-337. 
Felder, E. (ed.) (2006). Semantische Kämpfe. Macht und Sprache in den Wissenschaften. Berlin: de Gruyter.

Fluck, H. R. (1988). Zur Analyse und Vermittlung der Textsorte „Abstract”. In C. Gnutzmann (ed.), Fachbezogener Fremdsprachenunterricht. Tübingen: Narr, 67-90.

Fluck, H. R. (2001). Naturwissenschaftliche und technische Fachtexte. In G. Helbig, L. Götze, G. Henrici \& H. J. Krumm (eds.), Deutsch als Fremdsprache. Ein internationales Handbuch. 1. Halbband. Berlin: de Gruyter, 549-565.

Fluck, H. R. (2010). Fach- und Wissenschaftssprachen in den Naturwissenschaften. In Krumm et al. (eds.), 477-487.

Földes. C. (2005). Wissenschaftssprache und Wissenschaftskommunikation im Spannungsfeld zwischen Deutsch, Nationalsprache und Englisch. In E. Neuland, K. Ehlich \& W. Roggausch (eds.), Perspektiven der Germanistik in Europa. München: Iudicium, 258-272.

Fremde Wörter, Der Spiegel (Newspaper), 05 February 2001.

Galtung, J. (1985). Struktur, Kultur und intellektueller Stil. Ein vergleichender Essay über sachsonische, teutonische, gallische und nipponische Wissenschaft. In A. Wierlacher (ed.), Das Fremde und das Eigene. München: Iudicium, 448-459.

Gardt A. \& B. Hüppauf (eds.) (2004). Globalisation and the future of German. Berlin: de Gruyter.

Gnutzmann, C. (ed.) (2008). English in academia. Catalyst or barrier? Tübingen: Narr. Graefen G. \& M. Moll (2011). Wissenschaftssprache Deutsch: lesen-verstehen - schreiben. Ein Lehr- und Arbeitsbuch. Frankfurt am Main: Peter Lang.

Graefen, G. \& W. Thielmann (2007). Der wissenschaftliche Artikel. In Auer \& Baßler (eds.), 6797. 
Graefen, G. (1997). Der wissenschaftliche Artikel - Textart und Textorganisation. Frankfurt am Main: Peter Lang.

Graefen, G. (1999). Wie formuliert man wissenschaftlich? Materialien Deutsch als Fremdsprache 52, 222-239.

Graefen, G. (2009). Die Didaktik des wissenschaftlichen Schreibens: Möglichkeiten der Umsetzung. German as a Foreign Language 2, 106-127.

Granger, S. (1998). Prefabricated patterns in advanced EFL writing: collocations and formulae', in A.P. Cowie (ed.), Phraseology. Theory, analysis, and application. Oxford: Oxford University Press, 144-160.

Grütz, D. (2002). Die Vorlesung - eine fachsprachliche Textsorte. Hilfen zur Rezeption im Rahmen Deutsch als Fremdsprache am Beispiel der Fachkommunikation Wirtschaft. Linguistik Online 10.1, http://www.linguistik-online.de/10_02/gruetz.pdf.

Guckelsberger, S. (2005). Mündliche Referate in universitären Lehrveranstaltungen, Diskursanalytische Untersuchungen im Hinblick auf eine wissenschaftsbezogene Qualifizierung von Studierenden. München: Iudicium.

Günthner, S. \& H. Knoblauch (2007). Wissenschaftliche Diskursgattungen - Power Point at al. In Auer \& Baßler (eds.), 53-65.

Hamp-Lyons, L. (2011). Editorial English for academic purposes: 2011 and beyond. Journal of English for Academic Purposes 10, 2-4.

Heine, A. (2010). Fach- und Wissenschaftssprachen in den Ingenieurwissenschaften. In Krumm et al. (eds.), 487-493.

Heinemann, M. (2001). Textsorten des Bereichs Hochschule und Wissenschaft. In Brinker et al. (eds.), 702-709.

Heinemann, W. \& D. Viehweger (1991). Textlinguistik. Eine Einführung. Tübingen, Niemeyer. 
Heller, D. (2006). L'autore traccia un quadro ... Beobachtungen zur Versprachlichung wissenschaftlichen Handelns im Deutschen und Italienischen. In Ehlich \& Heller (eds.), 6385.

Hinds, J. (1987). Reader versus writer responsibility: A new typology. In U. Connor \& R. B. Kaplan (eds.), Writing across languages: Analysis of L2 text. Reading, MA: Addison-Wesley, $141-152$.

Hinkel, E. (2004). Tense, aspect and the passive voice in L1 and L2 academic texts. Language Teaching Research 8.1, 5-29.

Hoffmann, L. (1998). Fachtextsorten der Wissenschaftssprache: das fachinterne Gutachten zu wissenschaftlichen Arbeiten. In Hoffmann et al. (eds.), 500-504.

Hoffmann, L., H. Kalverkämper, H. \& H. E. Wiegand (eds.) (1998). Fachsprachen-Languages for Special Purposes. Berlin: de Gruyter.

House, J. \& G. Kasper (1981). Politeness markers in English and German. In F. Coulmas (ed.), Conversational routine. Explorations in standardized communication situations and prepatterned speech. The Hague: Mouton, 157-185.

Hu, G. \& F. Cao (2011). Hedging and boosting in abstracts of applied linguistics articles: A comparative study of English- and Chinese-medium journals. Journal of Pragmatics 43, 2795-2809.

Hufeisen, B. (2002). Ein deutsches Referat ist kein englischsprachiges Essay: theoretische und praktische Überlegungen zu einem verbesserten textsortenbezogenen Schreibunterricht in der Fremdsprache Deutsch an der Universität. Innsbruck: Studien-Verlag. Hutz, M. (2001). „Insgesamt muss ich leider zu einem ungünstigen Urteil kommen.” Zur Kulturspezifik wissenschaftlicher Rezensionen im Deutschen und Englischen. In U. Fix, St. 
Habscheid \& J. Klein (eds.), Zur Kulturspezifik von Textsorten. Tübingen: Stauffenburg, 109130.

Hyland, K. \& L. Hamp-Lyons (2002). EAP: issues and directions. Journal of English for Academic Purposes 1, 1-12.

Hyland, K. (1998). Hedging in scientific research articles. Amsterdam: Benjamins.

Hyland, K. (2008). As can be seen: Lexical bundles and disciplinary variation. English for Specific Purposes 27.1, 4-21.

Jasny, S. (2001). Trennbare Verben in der gesprochenen Wissenschaftssprache und die Konsequenzen für ihre Behandlung im Unterricht für Deutsch als fremde Wissenschaftssprache. Regensburg: Materialien DaF 64.

Jaworska, S. (2009). The German language in British higher education: Problems, challenges, teaching and learning perspectives. Harrassowitz: Wiesbaden.

Jaworska, S. (2011). Der Wissenschaftlichkeit auf der Spur: Zum Einsatz von Korpora in der Vermittlung des Deutschen als (fremder) Wissenschaftssprache. Deutsch als Fremdsprache 4, $235-244$.

Kaplan, R. B. (1972). The anatomy of rhetoric: Prolegomena to a functional theory of rhetoric. Philadelphia, Center for Curriculum Development.

Khuwaileh, A.A. \& A. Al Shoumali (2000). Writing errors: a study of the writing ability of Arab learners of academic English and Arabic at university. Language, Culture and Curriculum $13.2,174-183$.

Koch, P. \& W. Oesterreicher (1985). Sprache der Nähe - Sprache der Distanz. Mündlichkeit und Schriftlichkeit im Spannungsfeld von Sprachtheorie und Sprachgeschichte. Romanistisches Jahrbuch 36, 15-43. 
Kretzenbacher H. L. \& H. Weinrich (eds.) (1995). Linguistik der Wissenschaftssprache. Berlin: de Gruyter.

Kretzenbacher, H. L. (1995). Wie durchsichtig ist die Sprache der Wissenschaften? In Kretzenbacher \& Weinrich (eds.), 15-39.

Kretzenbacher, H. L. (1998a) Fachsprache als Wissenschaftssprache. In Hoffmann et al. (eds.), $133-142$.

Kretzenbacher, H. L. (1998b). Fachtextsorten der Wissenschaftssprachen III: Abstract und Protokoll. In Hoffmann et al. (eds.), 493-499.

Kretzenbacher, H. L. (2010). Fach- und Wissenschaftssprachen in den Geistes- und Sozialwissenschaften. In Krumm et al. (eds.), 493-502.

Krishnamurthy, R. \& I. Kosem (2007). Issues in creating a corpus for EAP pedagogy and research. Journal of English for Academic Purposes 6, 356-373.

Krumm, H-J., Ch. Fandrych, B. Hufeisen \& C. Riemer (eds.) (2010). Handbuch Deutsch als Fremd- und Zweitsprache. Berlin: de Gruyter.

Kuhn, T. (1962). The structure of scientific revolution. Chicago: University of Chicago Press. Lenhardt, Ch. (1985). Reply to Hullot-Kentor. Telos 65, 147-152.

Liebert, W. A. (2006). Naturwissenschaftlicher Fachdiskurs als Kontroverse. In Felder (ed.), $251-287$.

Lobin, H. (2009). Inszeniertes Reden auf der Medienbühne. Zur Linguistik und Rhetorik der wissenschaftlichen Präsentation. Frankfurt am Main: Campus Verlag.

Markkanen, R. \& H. Schröder (1997). Hedging: a challenge for pragmatics and discourse analysis. In R. Markkanen \& H. Schröder (eds.), Hedging and discourse: Approaches to the analysis of a pragmatic phenomenon in academic texts. Berlin: de Gruyter, 3-18. 
Meer, D. (1998). Der Prüfer ist nicht der König: mündliche Abschlussprüfungen in der Hochschule. Tübingen: Niemeyer.

Meer, D. (2000). Möglichkeiten angewandter Gesprächsforschung: Mündliche Prüfungen an der Hochschule. Linguistik Online 5.1, http://www.linguistik-online.de/1_00/MEER.HTM.

Mehlhorn, G. (2005). Studienbegleitung für ausländische Studierende an deutschen Hochschulen. München: Iudicium.

Meißner, C. (2009). Figurative Verben in der alltäglichen Wissenschaftssprache des Deutschen. Eine korpuslinguistische Pilotstudie. Apples - Journal of Applied Language Studies 1, 93-116. Moll, M. (2001). Das wissenschaftliche Protokoll: vom Seminardiskurs zur Textart: empirische Rekonstruktionen und Erfordernisse für die Praxis. München: Iudicium.

Nesi, H. \& S. Gardner (2012). Genres across the disciplines. Cambridge: Cambridge University Press.

Niederhauser, J. (ed.) (1999). Wissenschaftssprache und Umgangssprache im Kontakt. Frankfurt am Main: Peter Lang.

Olszewska, D. (2006). Metakommunikativa zur Kennzeichnung des Texthandlungsmusters ILLUSTRIEREN. Studia Germanica Gedanensia 14, 113-129.

Paltridge, B. (2004). Academic writing. Language Teaching 37, 87-105.

Paquot, M. (2010). Academic vocabulary in learner writing: From extraction to analysis. London: Continuum.

Phillipson, R. (1992). Linguistic imperialism. Oxford: Oxford University Press.

Prestin, M. (2011). Wissenstransfer in studentischen Seminararbeiten. Rekonstruktion der Ansatzpunkte für Wissensentfaltung anhand empirischer Analysen von Einleitungen. München: Iudicium. 
Redder, A. (1990). Grammatiktheorie und sprachliches Handeln: „, denn” und „, da”. Tübingen: Niemeyer.

Redder, A. (2001). Modalverben in wissenschaftlicher Argumentation: Deutsch und Englisch im Vergleich. Jahrbuch Deutsch als Fremdsprache 27, 313-330.

Redder, A. (2008). Functional Pragmatics. In G. Antos \& E. Ventola (eds.), Interpersonal communication. Berlin: de Gruyter, 133-178.

Reershemius, G. (2012). Research cultures and the pragmatic functions of humor in academic research presentations: A corpus-assisted analysis. Journal of Pragmatics 44, 863-875.

Reinbothe, R. (2006). Deutsch als internationale Wissenschaftssprache und der Boykott nach dem Ersten Weltkrieg. Frankfurt am Main: Peter Lang.

Reuter, E. (2010). Fachsprache der Wirtschaft und des Tourismus. In Krumm et al. (eds.), 458467.

Ripfel, M. (1998). Fachtextsorten der Wissenschaftssprache II: die wissenschaftliche Rezension In Hoffmann et al. (eds.), 488-493.

Rogalla, H. (1986). German for academic purposes. Berlin: Langenscheidt.

Salager-Meyer, F. (1994). Hedges and textual communicative function in medical English written discourse. English for Specific Purposes 13.2, 149-170.

Salager-Meyer, F. (2008). Scientific publishing in developing countries: Challenges for the future. Journal of English for Academic Purposes 7, 121-132.

Schade, G. (2009). Einführung in die deutsche Sprache der Wissenschaften (13th edn). Berlin: Schmidt.

Scherner, M. (2006). “Text" - "Rede" - "Diskurs": Konkurrierende Begriffsbestimmungen in den Gründerjahren der Textlinguistik. In Felder (ed.), 373-394. 
Schiewe, J. (2007). Zum Wandel des Wissenschaftsdiskurses in Deutschland. In Auer \& Baßler (eds.), 31-49.

Schleef, E. (2009). A cross-cultural investigation of German and American academic style. Journal of Pragmatics 41, 1104-1124.

Schröder, H. (1991a). Linguistic and text-theoretical research on Languages for Special Purposes. In Schröder (ed.), 1-48.

Schröder, H. (ed.) (1991b). Subject-oriented texts. Languages for special purposes and text theory. Berlin: de Gruyter.

Siepmann, D. (2005). Discourse markers across languages. A contrastive study of second-level discourse markers in native and non-native text with implications for general and pedagogic lexicography. Abingdon, New York: Routledge.

Simpson-Vlach, R. \& N. C. Ellis (2010). An academic formulas list: New methods in phraseology Research. Applied Linguistics 31.4, 487-512.

Skudlik, S. (1990). Sprachen in den Wissenschaften. Deutsch und Englisch in der internationalen Kommunikation. Tübingen: Narr.

Smit, U. (2010). English as a lingua franca in higher education: A longitudinal study of classroom discourse. Berlin: de Gruyter.

Soll Deutsch als Wissenschaftssprache überleben? Die Zeit (Newspaper), 25 January 2011. Spillner, B. (1982). Formen und Funktionen wissenschaftlichen Sprechens und Schreibens. Loccumer Protokolle 6, 33-57.

Sprachfreies Denken gibt es nicht, Frankfurter Allgemeine Zeitung (Newspaper), 25 April 2008. Starke, G. \& T. Zuchewicz (2003). Wissenschaftliches Schreiben im Studium von Deutsch als Fremdsprache. Frankfurt am Main: Peter Lang. Statistisches Bundesamt. (2012). Bildung und Kultur: Studierende an Hochschulen. Wiesbaden. 
Steinhoff, T. (2007a). Zum ich-Gebrauch in Wissenschaftstexten. Zeitschrift für Germanistische Linguistik, 1-26.

Steinhoff, T. (2007b). Wissenschaftliche Textkompetenz. Sprachgebrauch und Schreibentwicklung in wissenschaftlichen Texten von Studenten und Experten. Tübingen: Niemeyer.

Stezano Cotelo, K. (2008). Verarbeitung wissenschaftlichen Wissens in Seminararbeiten ausländischer Studierender. Eine empirische Sprachanalyse. München: Iudicium.

Sucharowski, W. (2001). Gespräche in Schule, Hochschule und Ausbildung. In Brinker et al. (eds.), 1566-1576.

Sutherland-Smith, W. (2005). Pandora's box: academic perceptions of student plagiarism in writing. Journal of English for Academic Purposes 4.1, 83-95.

Swales, J. M. (1990). Genre analysis: English in academic and research settings. Cambridge: Cambridge University Press.

Thielmann, W. (2009). Deutsche und englische Wissenschaftssprache im Vergleich: Hinführen, Verknüpfen, Benennen. Heidelberg: Synchron.

Thurmair, M. (1991). Warten auf das Verb. Die Gedächtnisrelevanz der Verbklammer im Deutschen. Jahrbuch Deutsch als Fremdsprache 17, 174-202.

Tung, P., R. Lam \& W. K. Tsang (1997). English as a medium of instruction in post-1997 Hong Kong: What students, teachers, and parents think. Journal of Pragmatics 28.4, 441-459.

Ventola, E. (2007). Konferenzvorträge: Sprechen englisch muttersprachige Konferenzteilnehmer wirklich anders? In Auer \& Baßler (eds.), 115-132.

Weinrich, H. (1989). Formen der Wissenschaftssprache. Jahrbuch der Akademie der Wissenschaften zu Berlin, 119-158. 
Weinrich, H. (1993). Wissenschaftssprache, Sprachkultur und die Einheit der Wissenschaft. In H. Mainusch \& R. Toellner (eds.), Einheit der Wissenschaft. Opladen: Westdeutscher Verlag, $111-127$.

Wengeler, M. (2006). Mentalität, Diskurs und Kultur. Semantische Kämpfe in der deutschen Geschichtswissenschaft. In Felder (ed.), 157-183.

Ylönen, S. (2006). Training wissenschaftlicher Kommunikation mit E-Materialien. Beispiel mündliche Hochschulprüfung. In Ehlich \& Heller (eds.), 115-146.

Ylönen, S. (2010). Deutsch im medizinischen Kontext. In Krumm et al. (eds.), 467-477.

\footnotetext{
${ }^{1}$ See the ranking at: http://www.scimagojr.com/countryrank.php

${ }^{2}$ The report can be found at: http://www.britac.ac.uk/policy/language-matters/positionpaper.cfm.

${ }^{3}$ For further details, see the project website at: https://gewiss.uni-leipzig.de.

${ }^{4}$ Detailed information can be obtained from the project website at: http://www.euromobil.org/english/index.php.

${ }^{5}$ I would like to thank my colleague and translation scholar Dr. Stefan Baumgarten (Bangor University) for pointing to this reference.
} 